\title{
Review \\ Recent Developments in Metallic Nanomaterials for Cancer Therapy, Diagnosing and Imaging Applications
}

\author{
Dan Nicolae Păduraru ${ }^{1,2,+}$, Daniel Ion ${ }^{1,2,+}{ }^{+}$, Adelina-Gabriela Niculescu ${ }^{3}\left(\mathbb{D}\right.$, Florentina Mușat ${ }^{1,2,+}$,

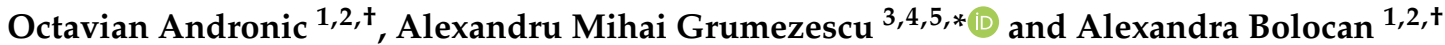 \\ 1 Carol Davila University of Medicine and Pharmacy, 050474 Bucharest, Romania; \\ dan.paduraru@umfcd.ro (D.N.P.); daniel.ion@umfcd.ro (D.I.); florentina.musat@drd.umfcd.ro (F.M.); \\ octavian.andronic@umfcd.ro (O.A.); alexandra.bolocan@umfcd.ro (A.B.) \\ 2 Emergency University Hospital of Bucharest, 050098 Bucharest, Romania \\ 3 Department of Science and Engineering of Oxide Materials and Nanomaterials, Faculty of Applied Chemistry \\ and Materials Science, Politehnica University of Bucharest, 011061 Bucharest, Romania; \\ adelina.niculescu@upb.ro \\ 4 Research Institute of the University of Bucharest-ICUB, University of Bucharest, 050657 Bucharest, Romania \\ 5 Academy of Romanian Scientists, Ilfov No. 3, 50044 Bucharest, Romania \\ * Correspondence: agrumezescu@upb.ro \\ + These authors contribute equally to this paper.
}

\section{check for}

updates

Citation: Păduraru, D.N.; Ion, D.;

Niculescu, A.-G.; Mușat, F.; Andronic,

O.; Grumezescu, A.M.; Bolocan, A.

Recent Developments in Metallic

Nanomaterials for Cancer Therapy,

Diagnosing and Imaging

Applications. Pharmaceutics 2022, 14,

435. https://doi.org/10.3390/

pharmaceutics14020435

Academic Editors: Sophie Laurent and Sébastien Penninckx

Received: 29 January 2022

Accepted: 14 February 2022

Published: 17 February 2022

Publisher's Note: MDPI stays neutral with regard to jurisdictional claims in published maps and institutional affiliations.

Copyright: (c) 2022 by the authors. Licensee MDPI, Basel, Switzerland. This article is an open access article distributed under the terms and conditions of the Creative Commons Attribution (CC BY) license (https:// creativecommons.org/licenses/by/ $4.0 /)$.

\begin{abstract}
Cancer continues to represent a global health concern, imposing an ongoing need to research for better treatment alternatives. In this context, nanomedicine seems to be the solution to existing problems, bringing unprecedented results in various biomedical applications, including cancer therapy, diagnosing, and imaging. As numerous studies have uncovered the advantageous properties of various nanoscale metals, this review aims to present metal-based nanoparticles that are most frequently employed for cancer applications. This paper follows the description of relevant nanoparticles made of metals, metal derivatives, hybrids, and alloys, further discussing in more detail their potential applications in cancer management, ranging from the delivery of chemotherapeutics, vaccines, and genes to ablative hyperthermia therapies and theranostic platforms.
\end{abstract}

Keywords: metal-based nanoparticles; nanomedicine; metallic anticancer agents; cancer therapy; drug delivery; hyperthermia; radiotherapy; phototherapy; combined cancer therapies

\section{Introduction}

Cancer comprises a complex array of diseases that represent one-third of the leading causes of morbidity and mortality worldwide. As traditional therapeutic approaches (i.e., chemotherapy, radiotherapy, and surgery) may result in severe adverse effects or/and unsatisfactory treatment outcomes, intense research has been shifted to integrating nanotechnology in cancer management [1-4].

Nanomedicine, the overlapping field of nanotechnology and medicine, brings a series of advantages over conventional cancer therapeutics, including multifunctionality, efficient drug delivery, and controlled release of chemotherapeutic agents. These benefits are possible due to the unique physical and chemical properties of nanoparticles (NPs), such as small size, chemical composition, large surface area, tailored shape, and morphology [5-9].

Whether based on polymeric, liposomal, or metallic formulations, NPs naturally traffic to the spleen and lymph organs, being good candidates for delivering immunotherapeutic agents [8]. Moreover, nanomaterials can be used as cytotoxics and/or enhancers of standard chemotherapies, diminishing the side effects associated with conventional drugs, extending their blood circulation time, and preventing drug degradation before reaching the target site $[1,10]$.

Metal-based NPs are particularly appealing in nanomedicine due to their relatively narrow size and shape distribution, long activity period, dense surface functionalization, 
and capability for optical or heat-based therapeutic strategies. Compared to nonmetallic NPs of similar sizes, the higher density of metallic NPs allows them to be more readily taken up by cells, thus proving advantageous for cancer management strategies $[8,11]$. In addition, metal NPs were reported to offer better targeting, gene silencing, and drug delivery, especially when functionalized with targeting ligands that provide controlled deposition into tumor cells [6].

Metallic nanoconstructs can remodel the tumor microenvironment (TME) by turning unfavorable conditions into therapeutically accessible ones. For instance, external stimuli (e.g., light, heat, ultrasonic radiation, and magnetic fields) can enhance the targeting ability of metallic NPs towards altering the redox potential of biological systems and generating reactive oxygen species (ROS) that further sensitize target tissues [12]. Furthermore, certain metallic NPs can induce oxidative stress in cancer cells even in the absence of external stimulation $[13,14]$; internal conditions specific to tumor tissues, such as $\mathrm{pH}$, redox potential, and hypoxia, represent additional viable stimuli for triggering metal-based NPs activity and drug release, enhancing therapeutic efficacy. Furthermore, surface functionalization of metallic NPs with different organic molecules, macromolecules, or noble metal coatings is considered an excellent tool for stabilizing NPs and manipulating their properties towards responding to the above-mentioned stimuli (Figure 1) [12].

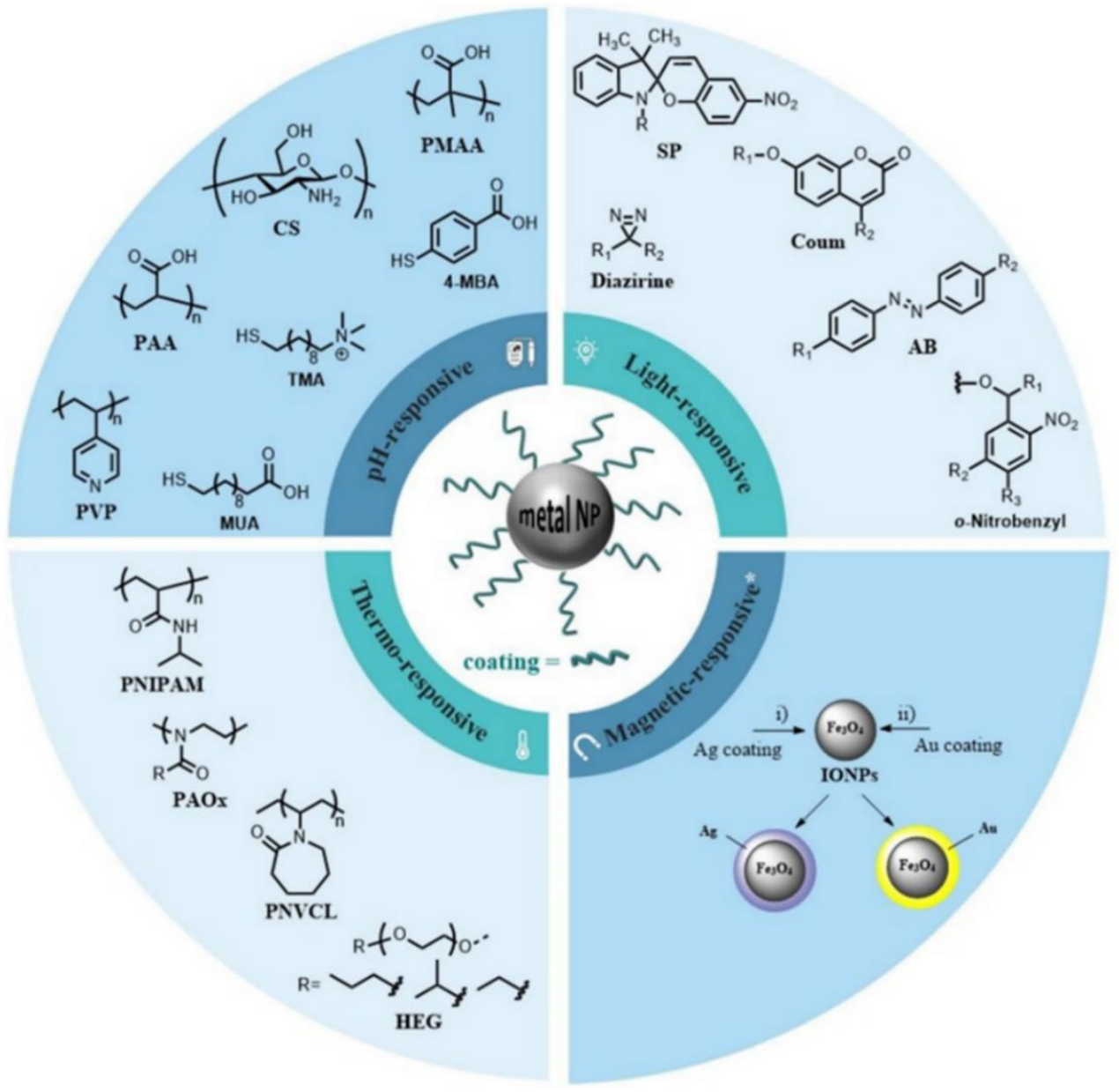

Figure 1. Examples of commonly used moieties for coating metal NPs to produce stimuli-sensitive nanosystems. Reproduced from [12].

Given these advantageous properties, numerous studies have investigated various metal-based nanoparticles as an innovative technology for fighting cancer. NPs made of metals (e.g., gold, silver, iron, zinc, titanium, cerium, and platinum), metal derivatives, 
metal alloys, metal hybrids, and combinations of metals with other nanomaterials have been increasingly reported in the specialty literature.

In this respect, the present paper aims to thoroughly review metallic nanomaterials that present attractive features for treating malignant diseases and present the possible applications of metal-based NPs in various therapeutic, diagnosis, and imaging approaches, focusing on the newest developments in the field.

\section{Metallic Nanomaterials}

\subsection{Gold NPs}

Gold nanoparticles (Au NPs) represent one of the most investigated metal-based NPs in medicine [15]. The appealing features of Au NPs count low toxicity and immunogenicity, good biocompatibility, excellent stability, enhanced permeability and retention, inherent immune activation properties, and easily modifiable surface $[1,8,11,16]$. Moreover, the developments achieved in various chemical and biological synthesis methods allowed the fabrication of Au NPs with tailored sizes, shapes, and structures (Figure 2), endowing them with desired properties. For instance, nanospheres' small surface area is particularly advantageous for creating efficient cytotoxic agents, and nanocages and nanoshells' inner cavities are appealing for drug encapsulation, while the large surface available to interact with light per unit of volume of nanorods recommends them for phototherapies. Thus, the versatility and tunability of $\mathrm{Au}$ NPs render them suitable for creating excellent delivery vehicles that can achieve targeting and selectivity against cancer cells even without additional molecules [1,17-20].

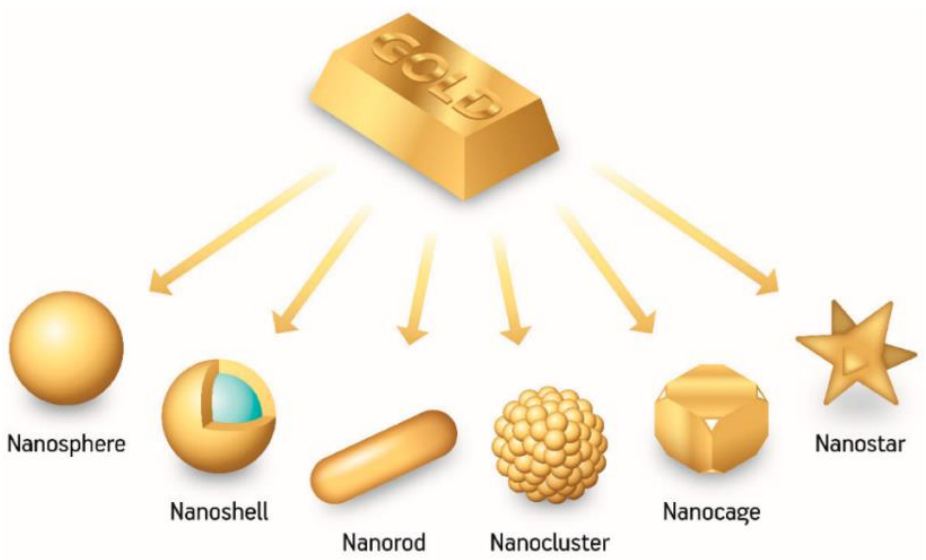

Figure 2. Visual representation of the most common Au NPs assemblies and morphologies in nanomedicine. Reproduced from [18].

$\mathrm{Au}$ NPs have also been reported to have tunable optical properties, surface plasmon resonance (SPR), photothermal properties, and surface-enhanced Raman scattering (SERS), being useful tools in phototherapy and photoimaging [16]. SPR is particularly important as this optical property allows Au NPs to be used in near-infrared (NIR)-resonant biomedical modalities, including magnetic resonance imaging (MRI), photoacoustic imaging (PAI), fluorescence imaging, and X-ray scatter imaging [21]. Moreover, Au NPs are of good use in cancer hyperthermia therapy. They can generate heat due to the contained mobile carriers that can be resonant at specific frequencies, depending on the structure of nanoplatforms. The heating effect increases under a plasmon resonance frequency, when all mobile carriers present on the particle resonate [22]. Other applications of Au NPs in cancer management include but are not limited to gene silencing, radiotherapy, and positron emission tomography (PET) imaging [6,21,23].

Additionally, green-synthesized Au NPs were demonstrated to have intrinsic antitumor properties [24], showing promising results when tested against several human cancer cell lines, counting liver cancer [25,26], lung cancer [27-29], colon cancer [30-32], 
pancreatic cancer [33,34], breast cancer [35,36], cervix carcinoma [37,38], and ovarian adenocarcinoma [39]. In what concerns the mechanisms of action, the particles were reported to enhance ROS production, change the mitochondrial membrane potential, inhibit the migration assay, activate caspase expression, and downregulate antiapoptotic protein expression, eventually resulting in antiproliferative effects and cancer cells apoptosis.

\subsection{Silver NPS}

Silver nanoparticles (Ag NPs) are another highly investigated material in nanomedicine. Ag NPs have been extensively explored due to their physicochemical and biological properties, including biocompatibility, large surface-to-volume ratio, potent antimicrobial activity, excellent SPR, ease of functionalization, and cytotoxicity against cancer cells [20,40].

Ag NPs have attracted increasing interest in the oncological domain, possessing intrinsic anticancer activity and being demonstrated as effective antitumor drug delivery systems [41,42]. Research has also proven that Ag NPs can modulate the autophagy of cancer cells, either acting as cytotoxic agents themselves, in combination with transported molecules, or in association with other treatments [1].

Concerning the mechanisms of anticancer action, Ag NPs were noted to affect membrane fluidity, resulting in facile entry and accumulation in cancer cells, thus causing cancer cells death or hindering their uncontrolled proliferation. Ag NPs can also act by regulating signaling pathways, inducing early apoptosis in the absence of the p53 tumor suppressor $[6,40,43]$. Moreover, NPs can release $\mathrm{Ag}^{+}$cations that capture electrons, increase intracellular oxidative stress, increase ROS production, reduce ATP levels of cancer cells, and decrease cell proliferation rates $[6,44] . \mathrm{Ag}^{+}$ions are reportedly released mainly in mitochondria and secondarily in the nuclei; there, they interact with DNA, resulting in its fragmentation and resulting in cell death $[43,45]$. The described Ag NPs mechanisms of action are visually represented in Figure 3; similar paths have also been proposed for other noble metal-based nanoparticles, including Au NPs [13,46], platinum NPs [47], and palladium NPs [48].

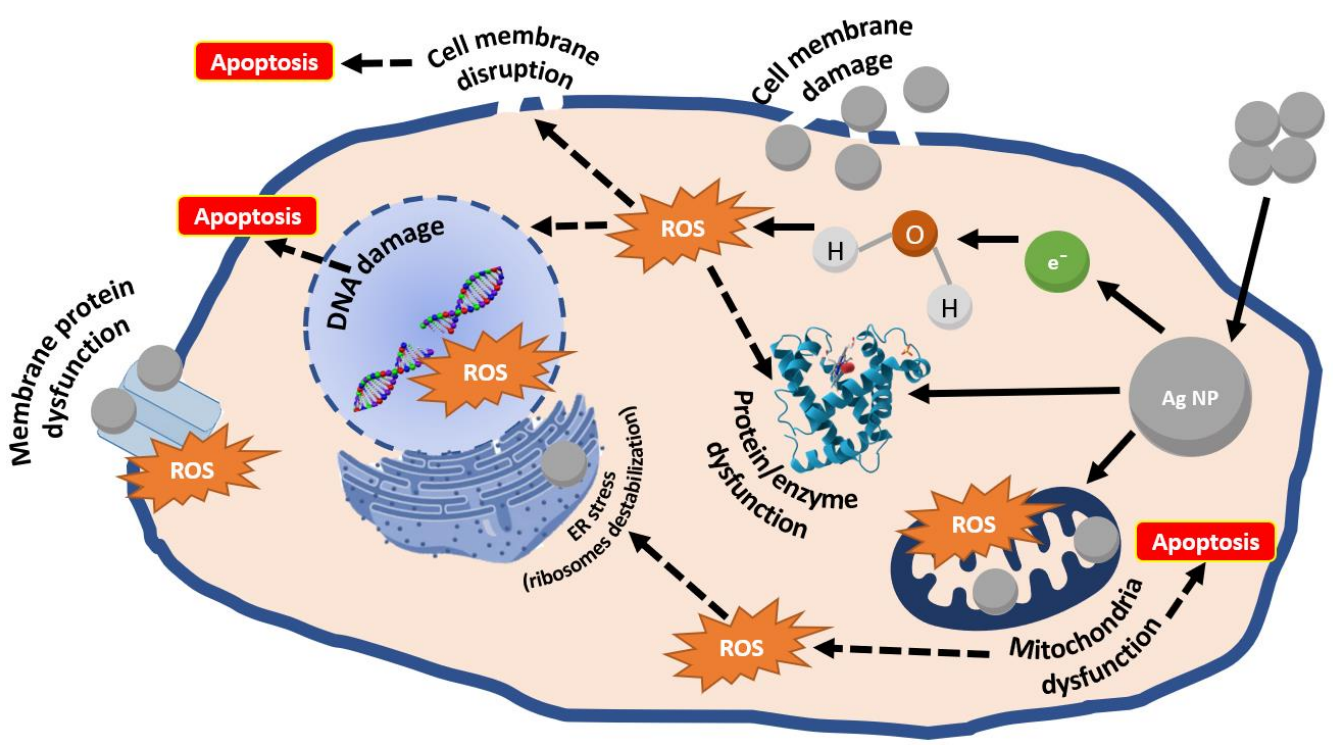

Figure 3. Schematic representation of Ag NPs anticancer mechanisms of action. Created based on information from $[44,49,50]$.

Significant results concerning Ag NPs antitumor activity were reported against several human cancer cell lines [43] (Table 1), including hepatocellular carcinoma [51-53], breast cancer [54-57], ovarian cancer [58,59], prostate cancer [60-62], colon cancer [30,63-66], lung cancer $[58,60,67,68]$, and osteosarcoma $[69,70]$. 
Table 1. Half-maximal inhibitory concentrations (IC50) of Ag NPs against various human cancer cell lines.

\begin{tabular}{cccc}
\hline Cancer Type & Cell Line & IC50 $(\mu \mathrm{g} / \mathrm{mL})$ & Ref. \\
\hline \multirow{2}{*}{ Liver cancer } & HepG2 & 48 & {$[52]$} \\
\cline { 2 - 4 } & HepG2 & 75 & {$[53]$} \\
\cline { 2 - 4 } Breast cancer & MCF-7 & 20 & {$[55]$} \\
\cline { 2 - 4 } & MCF-7 & 0.65 & {$[56]$} \\
\cline { 2 - 4 } & AU565 & 0.25 & {$[56]$} \\
\hline \multirow{2}{*}{ Ovarian cancer } & T47D & 5 & {$[57]$} \\
\cline { 2 - 4 } & PA-1 & 30 & {$[58]$} \\
\hline Prostate cancer & A2780 & 14.04 & {$[59]$} \\
\hline \multirow{2}{*}{ Colon cancer } & A2780Cis & $56.27 \pm 1.17$ & {$[60]$} \\
\hline & PC-3 & 50 & {$[30]$} \\
\hline & HCT-116 & 1.152 & {$[66]$} \\
\hline Lung cancer & HT29 & 28 & {$[68]$} \\
\hline Bone cancer & A549 & $11.28 \pm 1.28$ & {$[69]$} \\
\hline
\end{tabular}

\subsection{Iron Oxide NPS}

Different types of iron oxides found in nature have started to be explored for synthesizing magnetic NPs, such as magnetite $\left(\mathrm{Fe}_{3} \mathrm{O}_{4}\right)$, hematite $\left(\alpha-\mathrm{Fe}_{2} \mathrm{O}_{3}\right)$, and maghemite $\left(\gamma-\mathrm{Fe}_{2} \mathrm{O}_{3}\right.$ and $\left.\beta-\mathrm{Fe}_{2} \mathrm{O}_{3}\right)[3,71,72]$. Iron oxide nanoparticles (IONPs) exhibit many advantageous properties for biomedical applications, including non-toxicity, biocompatibility, superparamagnetism, chemical inertness, and easily tunable surface $[71,73,74]$.

Regarding cancer care, IONPs have been FDA-approved for clinical testing in cancer diagnosis, imaging, and magnetic hyperthermia therapy, also demonstrating potential in preclinical settings for photothermal and photodynamic therapies [75,76]. One particular ferrofluid formulation developed by MagForce AG has received approval for the treatment of brain tumors, their "NanoTherm" therapy being certified for use on patients from member states of the European Union [77]. IONPs have also been extensively researched for imaging applications. Iron oxide-based particles were noted to be promising contrast agents for different imaging modalities, counting MRI [78,79], fluorescence imaging [80], single-photon emission computed tomography (SPECT) [81], and multimodal imaging [82].

Moreover, IONPs have attracted particular interest in developing magnetic nanoparticle-based drug delivery systems. This is particularly because drug-loaded IONPs have strong targeting ability under external magnetic guidance (Figure 4). Specifically, by applying an external magnetic field, injected IONP-based delivery systems move through blood capillaries towards the desired site, releasing the drug in tumor cells, thus increasing therapeutic efficacy without damaging the neighboring normal cells [3,83]. In addition, their magnetic properties allow the transformation of radiant energy into heat or ROS after applying the local external magnetic field, reducing the adverse effects of cancer therapy [6].

Various such IONPs-based nanosystems have been tested in vitro and in vivo, being reported effective against several types of cancer, including breast cancer [84,85], lung cancer [86,87], liver cancer [88], gastric cancer [89], colorectal cancer [90], prostate cancer [91], and ovarian cancer [92]. The particles showed promising results either alone, in combination with other nanomaterials (e.g., copper, chitosan, aminosilane, and polyethylene 
glycol) or as carriers of different chemotherapeutic agents (e.g., doxorubicin, docetaxel, and curcumin).

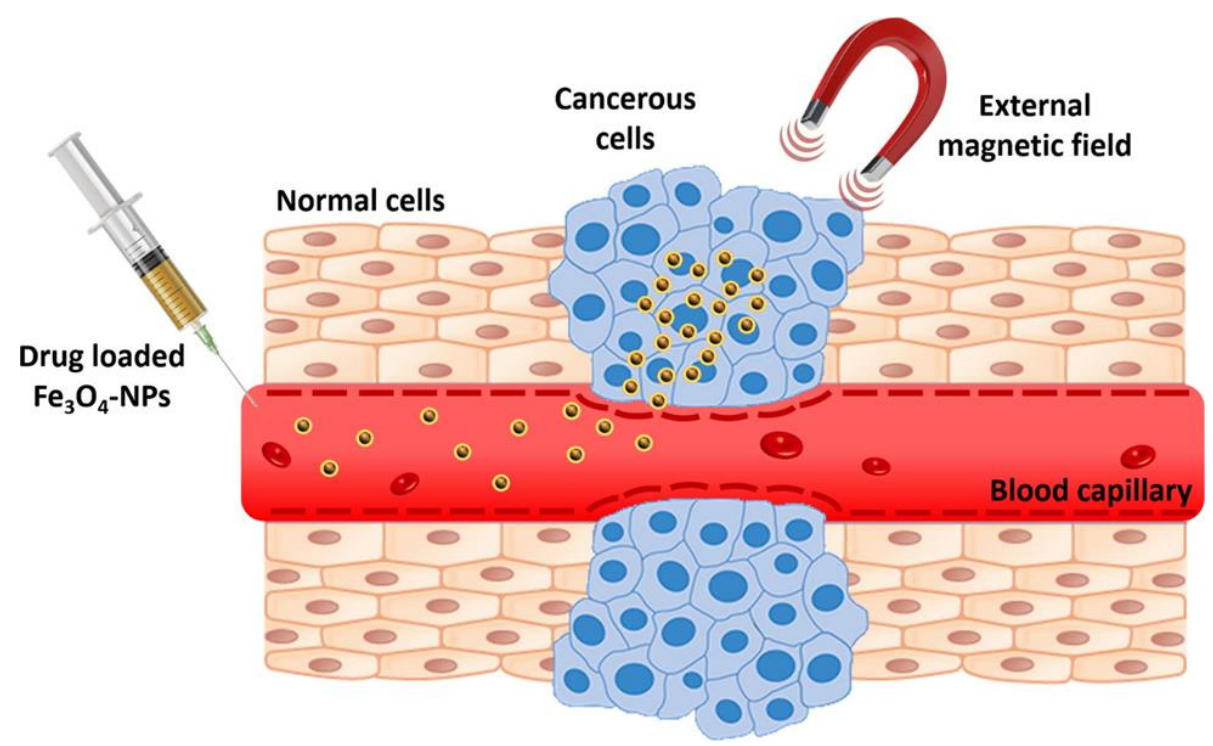

Figure 4. Schematic representation of targeted drug delivery using iron oxide NPs. Reproduced from [3], Elsevier B.V., 2020.

\subsection{Other Metal-Based Nanomaterials}

In addition to the above-discussed NPs, several other metals and metal derivatives started to be investigated in their nanoform as potential candidates for applications in cancer management. For instance, zinc oxide nanoparticles (ZnO NPs) have recently become used in biomedical and cancer applications due to their favorable chemical properties [1]. ZnO NPs exhibit good biocompatibility, antimicrobial, and anticancer activities, gaining increasing popularity in nanomedicine [93,94]. Moreover, ZnO NPs were reported to behave similarly to genotoxic drugs due to their ability to form micronucleus into the cells. This effect was noted to be maximum on glioblastoma multiforma tumor cells, medium on epithelial carcinoma cells, and absent on normal cells [6]. Anticancer activity was also reported for green-synthesized ZnO NPs against several other human cancer cell lines, including colon cancer [95,96], cervical cancer [96], breast cancer [96], lung cancer [97,98], laryngeal cancer [99], and osteosarcoma [100].

Cuprous and copper oxide NPs are other nanomaterials with potential applications in the biomedical field [101]. In particular, plant-synthesized NPs showed pharmacological effects in tumor therapy, such as inducing apoptosis, increasing ROS generation, inhibiting metastasis, and stimulating autophagic cell death [1,6] in colon cancer [102,103], esophageal cancer [104], lung cancer [105], breast cancer [106], cervical cancer [107], renal cell carcinoma [108], and melanoma [109].

Titanium dioxide NPs $\left(\mathrm{TiO}_{2} \mathrm{NPs}\right)$ represent a useful material for photodynamic therapy. Its mechanism of action is based on the excitation of hydrophobic molecules with electromagnetic radiation in the range of visible or UV light towards ROS generation and further induction of apoptosis [6]. Moreover, $\mathrm{TiO}_{2} \mathrm{NPs}$ were reported cytotoxic in several human cancer cell lines, such as colon cancer [110], breast cancer [111], and osteosarcoma [112].

Cerium oxide NPs have attracted interest in cancer management, especially in radiation therapy and drug delivery of chemotherapeutics. These NPs exhibit the smart capacity of inducing tumor cell death while leaving the surrounding healthy tissues unharmed by radiation and oxidative stress [6]. In this respect, recent studies investigated cerium oxide NPs anticancer potential for treating colon cancer [113,114], pancreatic cancer [115], breast cancer [116,117], and ovarian cancer [114]. 
Recent studies revealed that bio-synthesized palladium nanoparticles (Pd NPs) present antioxidant, anticancer, antimicrobial, antiproliferative, and photothermal activities while being biocompatible and less toxic than their chemically-synthesized counterparts [118]. Thus, they hold great promise in developing novel and improved cancer therapies, being already evaluated against several cancer cell lines (e.g., lung cancer [48], breast cancer [119], ovarian cancer [120], cervical cancer [121], and colorectal adenocarcinoma [121]).

Advantageous properties have also been reported for platinum nanoparticles (Pt NPs), resulting in increasing interest for applications in biotechnology, nanomedicine, and pharmacology fields. Specifically, Pt NPs exhibit potent antimicrobial, antioxidant, and anticancer activities; SPR; and photothermal properties, which are all highly valuable characteristics for designing performant nanotherapeutics, drug-delivery systems, and bioimaging agents [122-124].

\subsection{Hybrid Metal NPs and Metallic Alloy NPS}

In addition to their remarkable individual potential, metals can also be manufactured into hybrid metal NPs towards creating synergistic effects. For instance, bifunctional iron-gold NPs of different shapes, sizes, and structures (Figure 5) are being evaluated for biomedical applications, such as targeted drug delivery, biosensing, photothermal therapy, and immunoassays. The attention these NPs have drawn owes to their beneficial physicochemical properties, including low toxicity, small size, large surface-to-volume ratio, optical characteristics, slow oxidation, increased magnetic susceptibility, and high saturation magnetization [125].

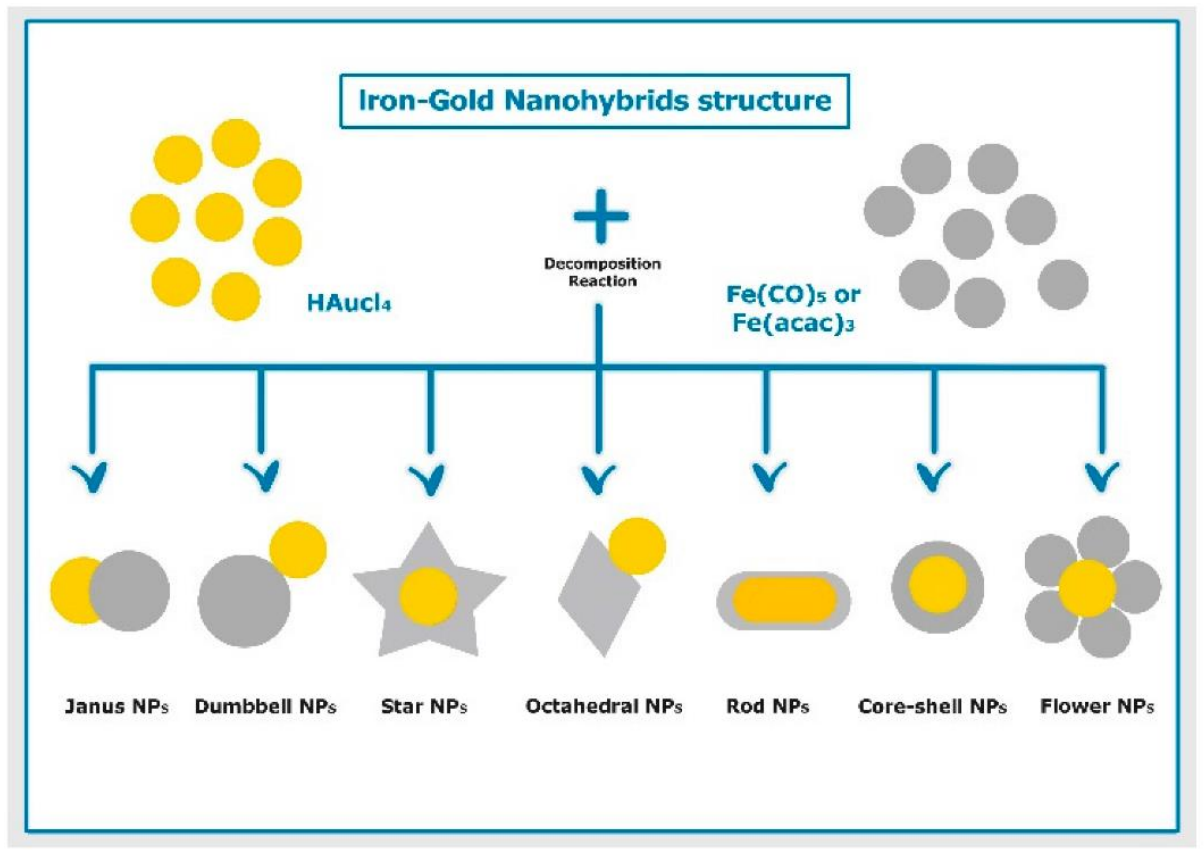

Figure 5. Schematic illustration of different structures of iron-gold hybrid nanoparticles prepared using thermal decomposition method. Reproduced from [125].

Other hybrid metal-based NPs that are relevant for cancer management include, but are not limited to, $\mathrm{MnSe} @ \mathrm{Bi}_{2} \mathrm{Se}_{3}$ core-shell nanostructures, $\mathrm{FeSe}_{2} / \mathrm{Bi}_{2} \mathrm{Se}_{3}$ nanoparticles, $\mathrm{Pt} @ \mathrm{Fe}_{2} \mathrm{O}_{3}$ nanorods, Au@FeS nanoparticles, Au@Pt nanodendrites, Au@MnO $\mathrm{Mn}_{2}$ nanoparticles, and Au@Se nanoparticles [126].

Synergistic effects were also reported when using bimetallic (Figure 6) and trimetallic alloy nanoparticles, which are progressively studied for various applications. Compared to monometallic NPs, alloy NPs benefit from more stable structures and improved properties, possessing superior qualities in biomedical imaging. In particular, iron-based alloy NPs 
(e.g., Fe-Ni and Fe-Pt) have been employed in MRI as potential contrast agents due to their high magnetic or superparamagnetic property and low toxicity in living cells [127].

(a)
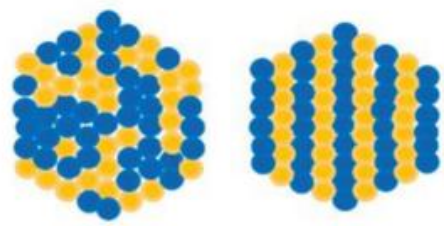

(c)

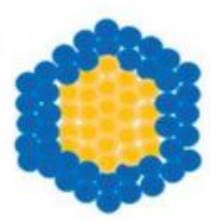

(b)

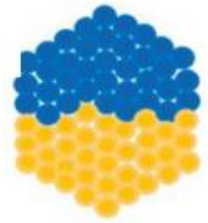

(d)

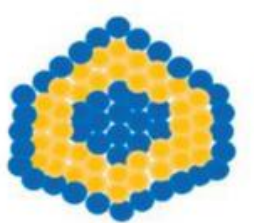

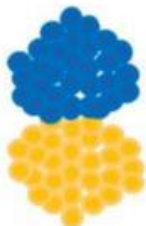

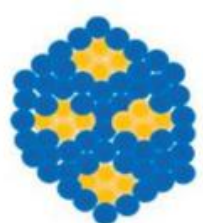

Figure 6. Types of bimetallic alloyed nanoparticles. (a) Mixed alloyed nanoparticles; (b) sub-cluster segregated alloyed nanoparticles; (c) core-shell alloyed nanoparticles; (d) multiple core-shell alloyed nanoparticles. Reproduced from [127].

\section{Discussion on Cancer Applications of Metallic Nanomaterials}

Either alone, as alloys, in various metallic combinations or in association with other nanomaterials, metal-based nanoparticles can be employed in a plethora of applications for better cancer management (Figure 7). In this respect, the following subsections review the role of metallic nanomaterials in detecting and treating cancer, describing some of the most recent advancements in these fields.

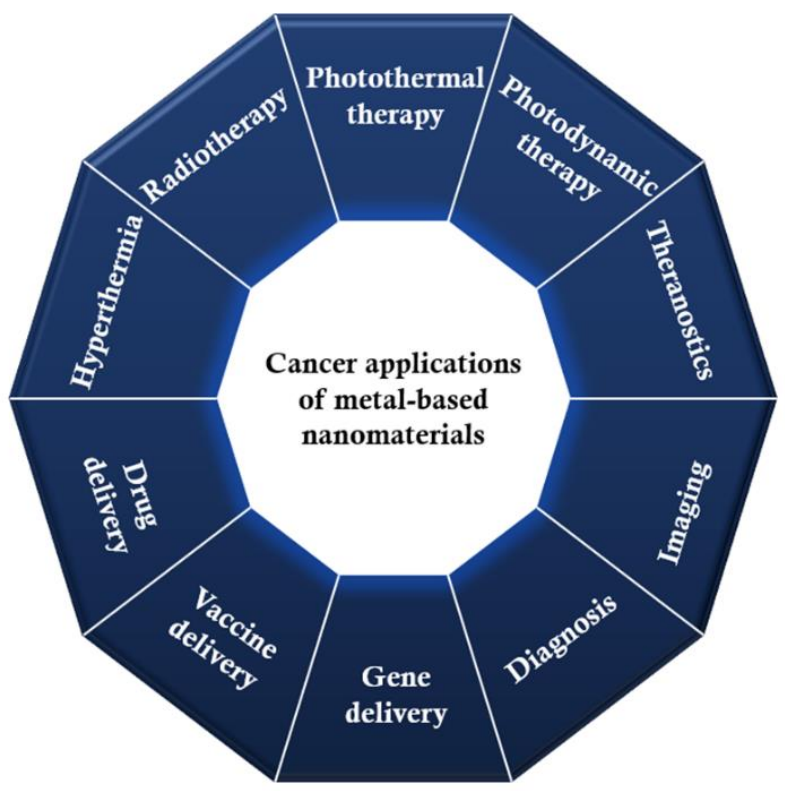

Figure 7. Applications of metal-based nanomaterials in cancer management.

\subsection{Drug Delivery}

Metal-based NPs can circumvent the limitations of conventional chemotherapy by providing targeted and controlled release of carried anticancer agents. Thus, carrying drugs via nanoplatforms made of gold, silver, or metal derivatives has become an intense research topic. Studies have reported promising results for a variety of metal-based nanocarriers, either in pristine form, functionalized with targeting moieties or coated with biocompatible layers. Such nanosystems have been proven to enhance in vivo stability, increase drug accumulation in the tumor site, improve the therapeutic effectiveness of carried drugs, 
and reduce systemic toxicity. Moreover, they can ensure sustained/programmable or ondemand drug release by responding to internal or external stimuli, respectively [128-130].

In order to emphasize the versatility of metal-based NPs for drug delivery, Table 2 has gathered several top-recent developments in the field. Moreover, Figure 8 offers a visual perspective over the discussed nanostructures.

Table 2. Examples of recently developed metal-based drug delivery systems for cancer therapy.

\begin{tabular}{|c|c|c|c|c|c|c|c|}
\hline Material & Morphology & Carried Drug & & Properties & & Results & Ref. \\
\hline Gold & $\begin{array}{l}\text { PEG-modified } \\
\text { nanospheres (with } \\
\text { Arg-Gly-Asp (RGD) } \\
\text { peptide as } \\
\text { targeting agent) }\end{array}$ & L-asparaginase & घ & $\begin{array}{l}\text { Average size: } \\
29.24 \pm 5.38 \mathrm{~nm}\end{array}$ & $\begin{array}{l}\text { - } \\
\text { - } \\
\text { - }\end{array}$ & $\begin{array}{l}\text { NPs improved drug bioavailability and } \\
\text { anticancer activity } \\
\text { Significant antioxidant effects } \\
\text { High tumor-targeting efficacy and } \\
\text { distribution in MCF-7 cells } \\
\text { Initiation of apoptosis and promotion of } \\
\text { cell cycle arrest at the G2/M } \\
\text { Upregulated pro-apoptotic p53, while } \\
\text { downregulating antiapoptotic Bcl-2 }\end{array}$ & [131] \\
\hline Silver & Nanospheres & Paclitaxel & घ & $\begin{array}{l}\text { Average size: } \\
\sim 10 \mathrm{~nm}\end{array}$ & - & $\begin{array}{l}\text { Nontoxic to noncancerous HUVEC cells } \\
\text { More effective than paclitaxel alone in } \\
\text { all tested cells (i.e., MDA-MB-231, } \\
\text { MCF-7, } 4 \text { T1, Saos-2) } \\
\text { Saos- } 2 \text { cells were } ~ 10 \text { times more } \\
\text { sensitive to paclitaxel-bonded Ag NPs } \\
\text { that to the bare drug }\end{array}$ & [132] \\
\hline Silver & $\begin{array}{c}\text { Nanospheres (coated } \\
\text { with starch) }\end{array}$ & $\begin{array}{l}\text { Euphorbia } \\
\text { dracunculoides } \\
\text { Lam. (EDL) plant } \\
\quad \text { extract }\end{array}$ & ๘ & $\begin{array}{l}\text { Average size: } \\
42.5 \pm 1.54 \mathrm{~nm} \\
\text { Loading capacity: } \\
\text { up to } 82.5 \% \\
\text { Encapsulation } \\
\text { efficiency: up } \\
\text { to } 85 \% \\
\text { Zeta potential: } \\
-29.64 \pm 0.09 \mathrm{mV}\end{array}$ & $\begin{array}{l}\text { - } \\
\text { - } \\
\text { - }\end{array}$ & $\begin{array}{l}\text { The surface modification increased } \\
\text { biocompatibility } \\
\text { pH-triggered drug release } \\
\text { Enhanced antioxidant potential } \\
\text { Accumulation in cancer cells and } \\
\text { induction of early and late apoptosis in } \\
\text { RAW264.7 and SCC7 cells }\end{array}$ & [133] \\
\hline Magnetite & $\begin{array}{l}\text { Nanospheres (coated } \\
\text { with polyvinyl } \\
\text { alcohol- } \\
\text { zinc/aluminum- } \\
\text { layered double } \\
\text { hydroxide) }\end{array}$ & Sorafenib & घ & $\begin{array}{l}\text { Average size: } \\
\sim 95 \mathrm{~nm} \\
\text { Saturation } \\
\text { magnetization: } \\
57 \text { emu/g } \\
\text { Remanent } \\
\text { magnetization: } \\
2.706 \mathrm{emu} / \mathrm{g}\end{array}$ & ๑ & $\begin{array}{l}\text { No cytotoxicity against } 3 \mathrm{~T} 3 \text { fibroblasts } \\
\text { More potent than bare drug against } \\
\text { HepG } 2 \text { liver cancer cells } \\
\text { The drug was more easily released } \\
\text { under an acidic environment }\end{array}$ & [134] \\
\hline Magnetite & $\begin{array}{l}\text { Nanospheres (surface } \\
\text { modified with } \\
\text { Pluronic F127 and } \\
\text { branched } \\
\text { polyethylenimine) }\end{array}$ & Doxorubicin & - & $\begin{array}{l}\text { Size range: } \\
\text { 10-20 nm } \\
\text { Zeta potential: } \\
\text {-20.5-4.87 } \mathrm{mV} \\
\text { Saturation } \\
\text { magnetization: } \\
54.5-65.5 \mathrm{emu} / \mathrm{g}\end{array}$ & - & $\begin{array}{l}\mathrm{pH}-/ \text { thermo-responsive drug delivery } \\
\text { system } \\
\text { Sufficient magnetic strength to allow } \\
\text { navigation towards the desired site } \\
\text { Enhanced the therapeutic effect of the } \\
\text { drug }\end{array}$ & [135] \\
\hline Maghemite & $\begin{array}{l}\text { Hollow nanospheres } \\
\text { (functionalized with } \\
\text { polyethylene glycol) }\end{array}$ & Doxorubicin & - & $\begin{array}{l}\text { Average } \\
\text { hydrodynamic size: } \\
\sim 175 \mathrm{~nm} \\
\text { Specific surface } \\
\text { area: } 266.1 \mathrm{~m}^{2} / \mathrm{g} \\
\text { Saturation } \\
\text { magnetization: } \\
16.3 \mathrm{emu} / \mathrm{g}\end{array}$ & ๘ & $\begin{array}{l}\text { Highly sensitive to alternating magnetic } \\
\text { field and } \mathrm{pH} \\
\text { Precise drug release to desired tissues }\end{array}$ & [136] \\
\hline
\end{tabular}


Table 2. Cont.

\begin{tabular}{|c|c|c|c|c|c|c|c|}
\hline Material & Morphology & Carried Drug & & Properties & & Results & Ref. \\
\hline Nickel oxide & $\begin{array}{c}\text { Honeycomb- } \\
\text { structured } \\
\text { nanoparticles (coated } \\
\text { with folic } \\
\text { acid-decorated } \\
\text { polydopamine) }\end{array}$ & Quercetin & 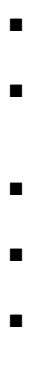 & $\begin{array}{l}\text { Average size: } \\
35 \mathrm{~nm} \\
\text { Average pore } \\
\text { volume: } \\
0.312 \mathrm{~cm}^{3} / \mathrm{g} \\
\text { Average pore size: } \\
11.44 \mathrm{~nm} \\
\text { Loading capacity: } \\
\text { up to } 51 \% \\
\text { Encapsulation } \\
\text { efficiency: } 51 \%\end{array}$ & $\begin{array}{l}\square \\
\square \\
\square\end{array}$ & $\begin{array}{l}\text { Surface modification increased } \\
\text { biocompatibility and reduced hemolysis } \\
\text { Highly controlled drug release in } \\
\text { physiological system compared to TME } \\
\text { Strong anticancer activity at very low } \\
\text { concentration } \\
\text { Cytotoxic effects against Vero cells and } \\
\text { MDA-MB-231 in a dose-dependent } \\
\text { manner }\end{array}$ & [137] \\
\hline Zinc oxide & $\begin{array}{c}\text { Hexagonal shaped } \\
\text { nanoparticles }\end{array}$ & Quercetin & - & $\begin{array}{l}\text { Average size: } \\
21-39 \mathrm{~nm}\end{array}$ & $\begin{array}{l}\text { - } \\
\text { - } \\
\text { - }\end{array}$ & $\begin{array}{l}\mathrm{pH} \text {-dependent drug-release, with higher } \\
\text { releasing rate in acidic medium } \\
\text { Stable under physiological } \mathrm{pH} \text {, } \\
\text { indicating that the nanosystem can be } \\
\text { retained in the blood stream up to } \\
\text { particular time point without causing } \\
\text { considerable side effects } \\
\text { High biocompatibility with 3T3-L1 cells } \\
\text { Effective inhibition of breast cancer cells } \\
\text { (MCF-7) growth }\end{array}$ & [138] \\
\hline Cobalt ferrite & $\begin{array}{l}\text { Polygonal } \\
\text { nanoparticles } \\
\text { (coated with } \\
\text { chitosan) }\end{array}$ & Doxorubicin & - & $\begin{array}{l}\text { Average size: } \\
38 \mathrm{~nm} \\
\text { Saturation } \\
\text { magnetization: } \\
50 \mathrm{emu} / \mathrm{g} \\
\text { Drug loading: up } \\
\text { to } \sim 89 \%\end{array}$ & $\begin{array}{l}\square \\
\square \\
\square\end{array}$ & $\begin{array}{l}\text { Excellent biocompatibility } \\
\text { Non-toxic nanosystem } \\
\text { High drug-release at the pH of cancer } \\
\text { tissue } \\
\text { Good cell death rates in breast cancer } \\
\text { cell line MCF-7 cells }\end{array}$ & [139] \\
\hline $\begin{array}{l}\text { Copper } \\
\text { oxide }\end{array}$ & $\begin{array}{l}\text { Nanospheres (coated } \\
\text { with bovine serum } \\
\text { albumin) }\end{array}$ & Methotrexate & - & $\begin{array}{l}\text { Average size: } \\
23.78 \pm 1.52 \mathrm{~nm} \\
\text { Loading efficiency: } \\
8.70 \pm 2.11 \%\end{array}$ & - & $\begin{array}{l}\text { Significant cytotoxicity against } \\
\text { MDA-MB- } 231 \text { cell line } \\
\text { Faster drug release in the presence of } \\
\text { proteinase K enzyme }\end{array}$ & [140] \\
\hline
\end{tabular}

As it can be observed from Table 2, not only the classic trio of metal-based nanomaterials (i.e., gold, silver, and iron oxide) have resulted in promising drug delivery applications, but also less investigated materials (e.g., cobalt ferrite, cobalt oxide, and nickel oxide) can be successfully employed in cancer therapy. The tested particles showed enhanced anticancer activity compared to bare chemotherapeutic drugs (even up to 10 times for silver NPs in certain cell lines [132]). Furthermore, the harmful potential of the carrier metals and carried drugs towards healthy tissues was reduced by adding biocompatible polymers, proteins, and targeting agents. Moreover, the differences in the biological activity of the presented nanosystems can be explained by their size and shape variability, nanospheres of smaller diameters being preferentially taken up by the target cells compared to their larger counterparts with different morphologies.

Another interesting novel approach is the use of supramolecular drug self-delivery systems (SDSDSs), which comprise active drug-building blocks linked through supramolecular interactions. One metal-based SDSDS is proposed by Liu et al. [141], who have developed platinum-containing supramolecular drug self-delivery nanomicelles (SDSDNMs) able to inhibit tumor growth while preserving good safety towards normal organs (Figure 9). The authors concluded that the newly designed system might provide promising opportunities in the field of synergistic combination chemotherapy. 
(A)

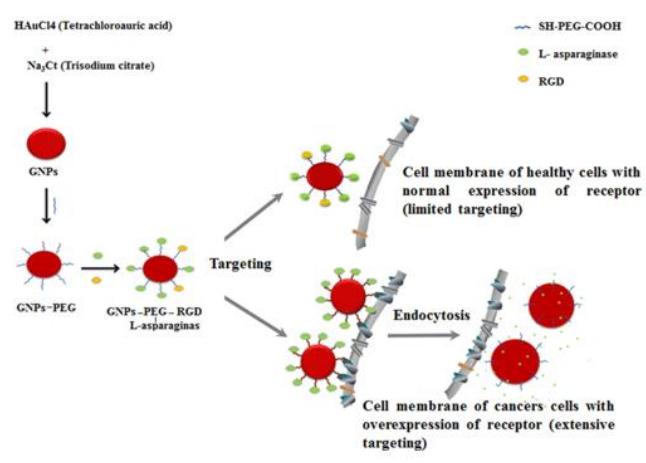

(C)

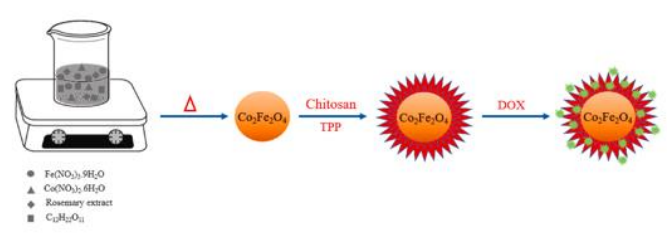

(B)

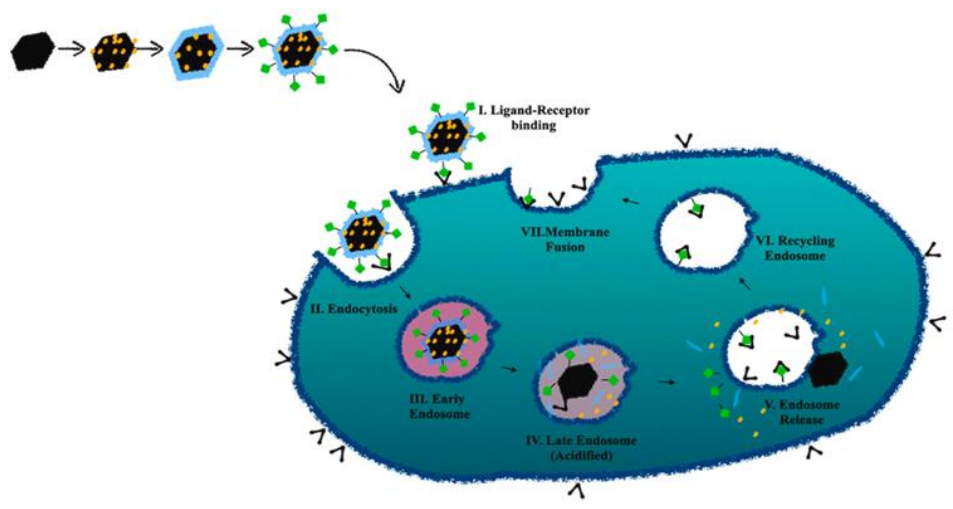

(D)

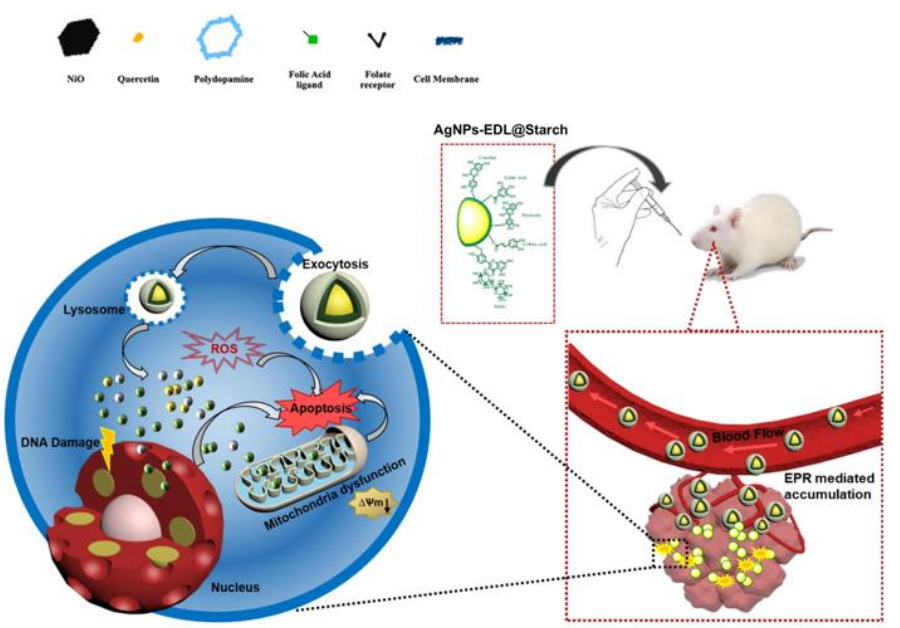

Figure 8. (A) Schematic representation of the formation of Gold NPs-PEG-RGD-Asparaginase (conjugate) and cellular uptake. Adapted from [131], Elsevier B.V., 2020. (B) Schematic representation of formation of honeycomb structured nickel oxide nanoparticles and intracellular drug release mechanism. Reproduced with permission from [137], Elsevier B.V., 2021. (C) Schematic representation of the preparation and final structure of cobalt ferrite NPs for doxorubicin delivery. Reproduced with permission from [139], Elsevier B.V., 2021. (D) Schematic representation of EDL-encapsulated AgNPs oral administration and cancer therapy mechanism of AgNPs-EDL@Starch. Reproduced with permission from [133], Elsevier B.V., 2021.

One more drug delivery strategy gaining interest in recent years is the use of implantable systems for targeted delivery without involving an external magnet. Specifically, implants can be employed as delivery vehicles of drugs, antimicrobial, anti-inflammatory, and immunomodulatory agents to desired sites, including surgery cavities to prevent potential cancer recurrence. Nonetheless, specific requirements must be fulfilled by these implants, counting drug release at a proper concentration and distance from the tumor, biocompatibility, antibacterial activity, and ability to surpass immune system recognition [142]. In this respect, Ge et al. [143] have created an iron oxide/poly(lactic-co-glycolic acid) implant scaffold with high magnetism (up to $40 \% w / w$ magnetic beads). The designed scaffold is biocompatible, durable, and effectively attracts nanodrugs to its surface, achieving targeted delivery without the application of an external magnetic field. Thus, it aids in the accumulation of drugs to tumor cells, improving therapeutic outcomes. This approach holds great promise for developing more precise medical treatments in the future. 
(A)

(B)

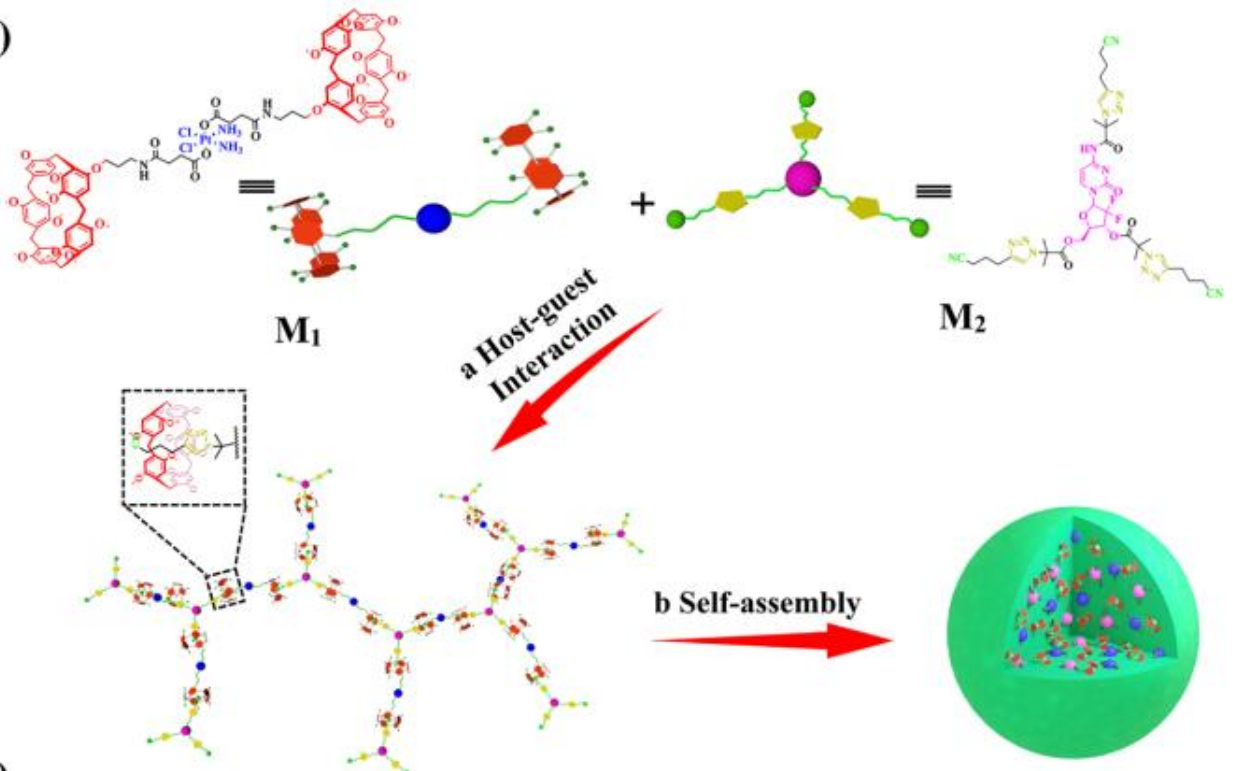

Drug-based supramolecular polymer

SDSDNMs

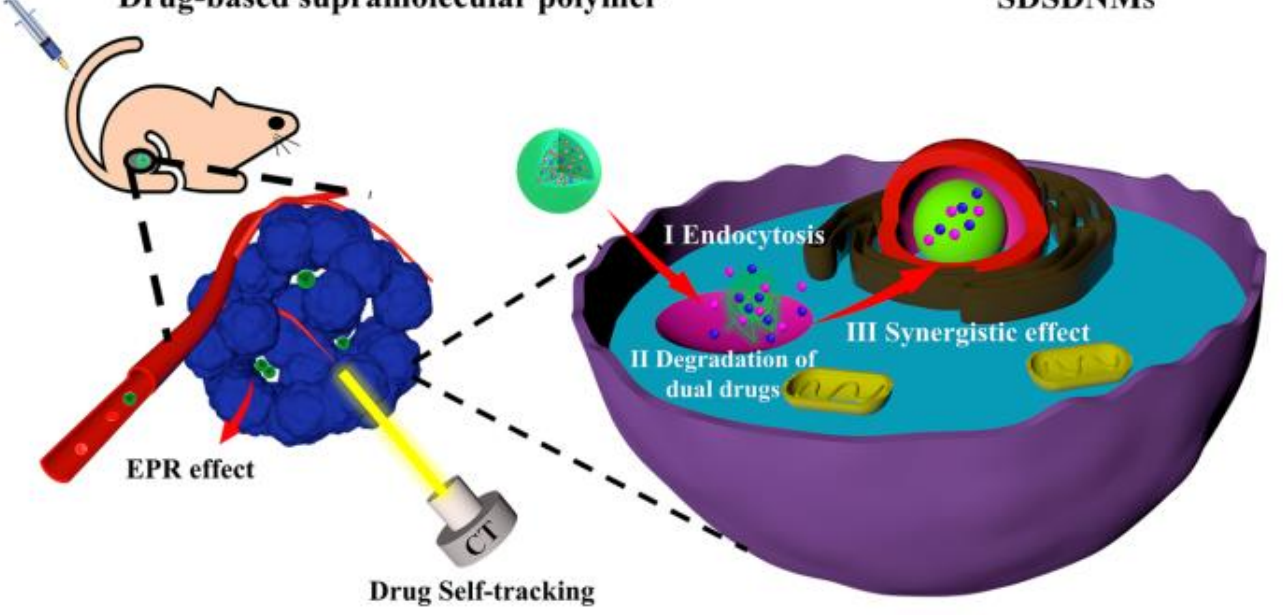

Figure 9. Schematic representation of the SDSDNMs developed by Liu et al. [141]. (A) Construction process. (B) Accumulation at the tumor site. Reproduced with permission from [141], American Chemical Society, 2021.

\subsection{Vaccine and Gene Delivery}

In addition to the use of chemotherapeutic agents, cancer vaccination represents another effective method for preventing or curing cancers. Cancer vaccines are based on tumor antigens administered as nucleic acids, tumor lysates, full proteins, or short peptides that can induce strong cellular and humoral immunity. Nonetheless, vaccines necessitate adjuvants to reach their maximum efficacy potential, improve the strength and longevity of immune responses, and reduce doses and side effects [144-147].

In this respect, metalloimmunology has the potential to revitalize cancer vaccines, as nutritional metal ions (e.g., $\mathrm{Ca}^{2+}, \mathrm{K}^{+}, \mathrm{Fe}^{2+/ 3+}, \mathrm{Zn}^{2+}$, and $\mathrm{Mn}^{2+}$ ) play important roles in many biological activities, including key immune processes. Thus, a wide variety of metals can be considered good adjuvants for nanovaccines, enhancing the generated immune responses through transcellular or intracellular signaling cascades against neoplastic transformation. More specifically, metal ions are suitable candidates for ensuring abrupt and timely immune responses, achieving effective immune regulation, and producing fewer toxicity concerns than conventional therapies [144]. Moreover, metallic NPs can be used as antigen delivery vehicles, being able to improve their uptake by dendritic cells (DCs) (or 
other antigen-presenting cells); this is further reflected in an increased antitumor cytotoxic $\mathrm{T}$ cell response [8].

Table 3 comprises several examples of metal-containing formulations for cancer vaccines delivery, highlighting the variety of tested materials.

Table 3. Examples of metal-based nanomaterials for cancer vaccine delivery.

\begin{tabular}{|c|c|c|c|c|c|}
\hline Material & Morphology & Immunogen & & Results & Ref. \\
\hline $\begin{array}{l}\text { Aluminum } \\
\text { hydroxide }\end{array}$ & $\begin{array}{l}\text { Nanospheres } \\
\text { (modified with } \\
\text { polyethylenimine) }\end{array}$ & Ovalbumin & $\begin{array}{l}\text { - } \\
\text { - } \\
\text { - }\end{array}$ & $\begin{array}{l}\text { Easily internalized into DCs, ensuring antigen release } \\
\text { into their cytoplasm } \\
\text { Significantly inhibited tumor growth } \\
\text { Considerably increased cytokine IL-12 secretion and } \\
\text { expression of surface molecules CD } 80 \text { and CD } 86 \\
\text { Promoted the activation of tumor-associated T cells }\end{array}$ & [148] \\
\hline Iron oxide & Nanospheres & Ovalbumin & : & $\begin{array}{l}\text { Considerably promoted activation of immune cells } \\
\text { Significantly increased cytokine production } \\
\text { Induced potent humoral and cellular immune } \\
\text { responses }\end{array}$ & [149] \\
\hline Iron oxide & $\begin{array}{l}\text { Nanospheres } \\
\text { (coated with a lipid } \\
\text { bilayer) }\end{array}$ & $\begin{array}{l}\text { Endogenous tumor } \\
\text { antigens (ETAs) }\end{array}$ & - & $\begin{array}{l}\text { Able to capture ETAs from tumors and transport } \\
\text { them to lymph nodes } \\
\text { In combination with anti-PD-L1 checkpoint blockade } \\
\text { could eliminate primary tumors, suppress distant } \\
\text { tumors, inhibit metastasis, and prolong the survival } \\
\text { of model animals }\end{array}$ & [150] \\
\hline Zinc oxide & Mesoporous nanocapsules & Ovalbumin & - & $\begin{array}{l}\text { Enhanced expression of antigen-specific T-cells } \\
\text { Induced IFN- } \gamma \text { producing effector CD } 4+\text { and CD8+ } \\
\text { T-cells } \\
\text { Increased antigen-specific IgG levels }\end{array}$ & [151] \\
\hline Zinc oxide & $\begin{array}{l}\text { Radially grown nanowires } \\
\text { on poly-L-lactide } \\
\text { microfibers }\end{array}$ & $\begin{array}{c}\text { Carcinoembryonic } \\
\text { antigen }\end{array}$ & $\begin{array}{l}\text {. } \\
\text {. } \\
\text {. } \\
\text {. }\end{array}$ & $\begin{array}{l}\text { Mild cellular toxicity } \\
\text { Effective delivery to DCs, stimulating them to express } \\
\text { inflammatory cytokines and activation surface } \\
\text { markers } \\
\text { Induced tumor antigen-specific cellular immunity } \\
\text { Significantly inhibited tumor growth } \\
\text { Reduced immune suppressive } T_{\text {Reg }} \text { cells } \\
\text { Enhanced the infiltration of T cells into tumor tissues }\end{array}$ & {$[152]$} \\
\hline $\begin{array}{l}\text { Magnesium- } \\
\text { aluminum- } \\
\text { layered double } \\
\text { hydroxide }\end{array}$ & Nanospheres & $\begin{array}{c}\text { Tyrosinase-related } \\
\text { protein } 2\end{array}$ & घ & $\begin{array}{l}\text { Induced strong cytotoxic T-lymphocyte responses } \\
\text { Significantly inhibited melanoma tumor growth } \\
\text { The NPs allow loading of multi-antigens and immune } \\
\text { stimulants, being promising for developing } \\
\text { personalized therapeutic cancer vaccines }\end{array}$ & {$[153]$} \\
\hline $\begin{array}{l}\text { Calcium } \\
\text { phosphate }\end{array}$ & $\begin{array}{c}\text { Nanospheres } \\
\text { (functionalized with } \\
\text { lipids) }\end{array}$ & $\begin{array}{l}\text { p-AH1-A5 peptide } \\
\text { antigen }\end{array}$ & - & $\begin{array}{l}\text { Reduced primary colon cancer growth rate } \\
\text { Arrested liver metastasis } \\
\text { Boosted the adaptive CD } 8+\text { T-cell population, } \\
\text { without inciting increased populations of immune } \\
\text { suppressive cell types (e.g., T-regulatory cells and } \\
\text { myeloid derived suppressor cells) }\end{array}$ & [154] \\
\hline
\end{tabular}

According to the studies presented in Table 3, it can be concluded that metal-based nanoformulations hold great promise for vaccine development in various forms, including nanospheres, nanocapsules, and nanowires. By delivering immunogens in a controlled manner, metal derivative nanoconstructs were observed to promote the activation of immune cells and significantly inhibit tumor growth. Moreover, in order to enhance the compatibility and stability of the particles in the biological media, researchers chose to coat them with polymer or lipid layers.

Following similar considerations of protecting the freight and enhancing induced cytotoxicity, metal nanoparticles can be used as carriers of negatively charged nucleotides (DNA and RNA), particularly due to their high positive surface charge. One specific phenomenon for which metal-based NPs hold great promise is gene silencing. They can carry antisense nucleotides that downregulate specific gene expression in tumor cells. As the strength and duration of the silencing response depends on the amount of siRNA 
delivered to the target site, metal NPs protective capacity can be enhanced by lipid or polymer coatings. Consequently, the load is not affected by RNase, increasing the half-life of siRNA and decreasing the required dose [6].

\subsection{Magnetic Hyperthermia}

A valuable tool in cancer management that uses the unique properties of metallic NPs is ablative hyperthermia [72]. This general term covers therapeutic approaches in which applied energy is transformed into heat by certain biocompatible metal-based nanomaterials. Increasing the temperature of tumor tissues kills cancer cells or sensitizes them to radiation or chemotherapeutic agents. Moreover, these therapeutic approaches increase blood flow in tumors, induce cytotoxicity, and disrupt tumor vasculature, further releasing tumor-specific antigens and danger signals that alert the immune systems. Thus, despite being only locally applied, ablative therapies may result in systemic immunity, exhibiting abscopal effects. In addition, ablative hyperthermia can be produced by external stimuli, including local external magnetic field (magnetic hyperthermia), radiofrequency (radiotherapy), and light of specific wavelength (photothermal therapy) $[1,8,155,156]$. Each of these therapies is further discussed in distinct consecutive sections.

Magnetic hyperthermia is the noninvasive technique in which an alternate magnetic field (AMF) remotely induces local heating through magnetic energy losses of magnetic nanoparticles. By ensuring precise uptake of magnetic NPs by tumor cells, the adverse effects in surrounding normal tissues can be significantly reduced. Generally, iron oxide NPs can be delivered intratumorally and heated at $41-50{ }^{\circ} \mathrm{C}$ under an AMF $[1,71]$. Nonetheless, other iron-containing nanoconstructs have been recently developed for application in cancer magnetic hyperthermia (Table 4, Figure 10).

Table 4. Examples of recently developed metal-based nanosystems for application in cancer magnetic hyperthermia.

\begin{tabular}{|c|c|c|c|}
\hline Material & Morphology & Properties & Ref. \\
\hline $\begin{array}{l}\text { Carbothermal treated } \\
\text { iron oxide }\end{array}$ & $\begin{array}{l}\text { Nanospheres with oxygen } \\
\text { vacancies }\end{array}$ & $\begin{array}{l}\text { - } \quad \text { Size range: } 5.1-225.6 \mathrm{~nm} \\
\text { - } \quad \text { Saturation magnetization: } 5.8-31.3 \mathrm{emu} / \mathrm{g} \\
\text { - } \quad \text { Specific absorption rate: up to } 71.6 \mathrm{~W} / \mathrm{g}\end{array}$ & [157] \\
\hline Magnetite & $\begin{array}{l}\text { Nanospheres } \\
\text { (coated with dextran) }\end{array}$ & $\begin{array}{l}\text { - } \quad \text { Average size: } 10 \mathrm{~nm} \\
\text { - } \quad \text { Saturation magnetization: } 40-60 \mathrm{emu} / \mathrm{g} \\
\text { - } \quad \text { Specific power absorption: } 132 \mathrm{~W} / \mathrm{g}\end{array}$ & [158] \\
\hline $\begin{array}{l}\text { Zn-substituted } \\
\text { magnetite }\end{array}$ & $\begin{array}{l}\text { Irregular hexagonal nanoparticles } \\
\text { (coated with citric acid and } \\
\text { pluronic F127) }\end{array}$ & $\begin{array}{l}\text { - } \quad \text { Mean hydrodynamic size: } 436-626 \mathrm{~nm} \\
\text { - } \quad \text { Specific loss power: up to } 539 \mathrm{~W} / \mathrm{g} \\
\text { - } \quad \text { Intrinsic loss power: up to } 7.26 \mathrm{nHm}^{2} \mathrm{~kg}^{-1}\end{array}$ & [159] \\
\hline Gd-doped maghemite & $\begin{array}{l}\text { Nanoparticles of almost spherical } \\
\text { shape along with some } \\
\text { aggregation }\end{array}$ & $\begin{array}{l}\text { - } \quad \text { Size range: } 8.73-11.06 \mathrm{~nm} \\
\text { - } \quad \text { Saturation magnetization: } 39.35-52.13 \mathrm{emu} / \mathrm{g} \\
\text { - } \quad \text { Specific absorption rate: up to } 140 \mathrm{~W} / \mathrm{g}\end{array}$ & [160] \\
\hline $\begin{array}{l}\text { Silver-iron oxide } \\
\text { composite }\end{array}$ & $\begin{array}{l}\text { Irregular-shaped particles } \\
\text { agglomerated to some extent }\end{array}$ & $\begin{array}{l}\text { - } \quad \text { Size range: } 2-24 \mathrm{~nm} \\
\text { - } \quad \text { Specific loss power: up to } 43 \mathrm{~W} / \mathrm{g} \\
\text { - } \quad \text { Intrinsic loss power: up to } 0.81 \mathrm{nHm}^{2} \mathrm{~kg}^{-1}\end{array}$ & [161] \\
\hline Iron oxide & $\begin{array}{l}\text { Cuboidal-shaped nanoparticles } \\
\text { (functionalized with CTAB) }\end{array}$ & $\begin{array}{l}\text { - } \quad \text { Average edge length: } \sim 80 \mathrm{~nm} \\
\text { - } \quad \text { Saturation magnetization: } 71 \mathrm{emu} / \mathrm{g} \\
\text { - } \quad \text { Specific loss power: up to } \sim 1036 \mathrm{~W} / \mathrm{g}\end{array}$ & [162] \\
\hline Cobalt ferrite & $\begin{array}{c}\text { Nanospheres } \\
\text { (coated with chitosan) }\end{array}$ & $\begin{array}{l}\text { - } \quad \text { Average size: } 13 \mathrm{~nm} \\
\text { - } \quad \text { Saturation magnetization: } \sim 62 \mathrm{emu} / \mathrm{g} \\
\text { - } \quad \text { Specific absorption rate: up to } 105 \mathrm{~W} / \mathrm{g}\end{array}$ & [163] \\
\hline Copper ferrite & Mesoporous spherical structures & $\begin{array}{l}\text { - } \quad \text { Hydrodynamic size: } \sim 91.2 \mathrm{~nm} \\
\text { - } \quad \text { Saturation magnetization: } \sim 32.7 \mathrm{emu} / \mathrm{g} \\
\text { - } \quad \text { Specific absorption rate: up to } \sim 192 \pm 7 \mathrm{~W} / \mathrm{g}\end{array}$ & [164] \\
\hline
\end{tabular}


Table 4. Cont.

\begin{tabular}{|c|c|c|c|c|}
\hline Material & Morphology & & Properties & Ref. \\
\hline Copper ferrite & Pseudo-cubical shaped particles & $\square$ & $\begin{array}{l}\text { Hydrodynamic size: } \sim 25.6 \mathrm{~nm} \\
\text { Saturation magnetization: } \sim 24.5 \mathrm{emu} / \mathrm{g} \\
\text { Specific absorption rate: up to } \sim 116 \pm 6 \mathrm{~W} / \mathrm{g}\end{array}$ & {$[164]$} \\
\hline Manganese ferrite & $\begin{array}{l}\text { Uniform nanospheres with some } \\
\text { agglomeration }\end{array}$ & & $\begin{array}{l}\text { Average size: } \sim 25 \mathrm{~nm} \\
\text { Saturation magnetization: } 54.18-59.67 \mathrm{emu} / \mathrm{g} \\
\text { Specific absorption rate: } 217.62 \mathrm{~W} / \mathrm{g}\end{array}$ & {$[165]$} \\
\hline
\end{tabular}

(A)

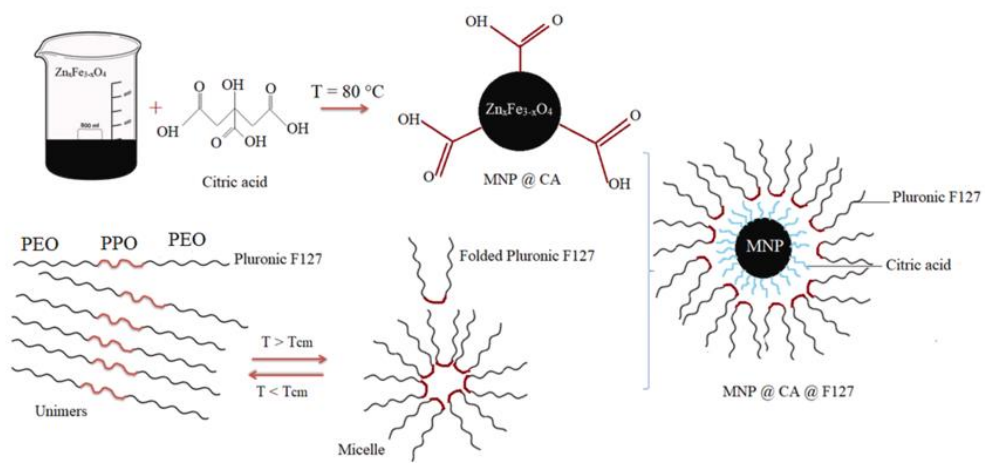

(B)

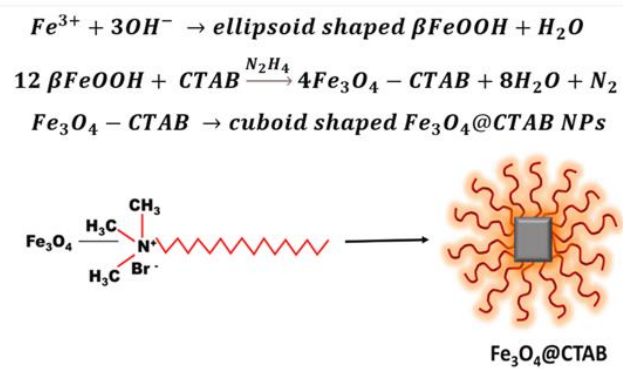

Figure 10. (A) Schematic representation of the surface modification of the magnetic nanoparticles with citric acid (CA) and pluronic F127. Reproduced with permission from [159], Elsevier B.V., 2022. (B) Schematic representation of the formation mechanism of $\mathrm{Fe}_{3} \mathrm{O}_{4} @ \mathrm{CTAB}$ nanocuboids. Reprinted with permission from [162], Elsevier B.V., 2021.

\subsection{Radiotherapy}

The inherent optical, electrical, and conductive properties of metal-based nanoparticles have rendered them appealing for use in radiotherapy. Metal NPs can increase the specificity of radiations to the desired site in such a manner that the maximum dose is delivered to the tumor tissue, while toxicity and damage are avoided in healthy tissues. Metal-based NPs were reported to increase intracellular ROS production from the ionizing radiations, increase oxidative stress levels in tumor cells, increase apoptosis rates, and reduce clonogenic survival $[5,6]$.

A variety of metals and metal derivatives can be used in radiotherapy, including gold, silver, platinum, titanium oxide, zinc oxide, and more. Metallic materials with atomic number between 22 and 83 have been researched in radiation therapy for a broad range of purposes, such as radiation dose enhancement, hyperthermia induction, controlled drug delivery, and theranostic applications [166]. In particular, the high atomic number and mass-energy coefficient of Au NPs and Ag NPs make them suitable candidates for radiosensitization in cancer imaging and therapy, while the unique physicochemical properties and high X-ray absorption efficiency of platinum-based or hafnium-based NPs recommend these nanoplatforms as ideal radiosensitizers [6,167].

Despite the physical concepts, the role of biological mechanisms has also started being investigated in recent years for radiosensitization purposes. Specifically, gold nanoparticles have been investigated whether they could influence cell response to radiation by five " $\mathrm{R}$ " factors (i.e., repair, redistribution, repopulation, reoxygenation, and intrinsic radiosensitivity) [46]. For instance, it has been reported that the presence of Au NPs produces a downregulation of thymidylate synthase, which is essential for DNA damage repair in the radioresistant S-phase cells [168]. Au NPs radiosensitisation ability has also been associated to a decrease in thioredoxin reductase (one of the main redox reactions regulators) activity, weakening the detoxification system [169]. 
Tumor tissues generally lack a proper amount of oxygen; thus, special strategies (Figure 11) must be considered for hypoxic conditions, as they contribute to chemoresistance and metastasis [142,170]. One interesting example is proposed by Chen et al. [171], who have prepared folic acid-modified enzyme-like hafnium-based manganoporphyrin metalorganic framework nanoparticles (MnTCPP-Hf-FA MOF NPs). The overall goal of the nanosystem was to overcome hypoxia-induced radioresistance and prevent a postoperative recurrence. Hf was chosen particularly due to its high atomic number and ability to absorb X-ray energy and convert $\mathrm{O}_{2}$ and $\mathrm{H}_{2} \mathrm{O}$ into ROS, while the MnTCPP ligand was included owing to its enzyme-like ability to decompose endogenous $\mathrm{H}_{2} \mathrm{O}_{2}$ into $\mathrm{O}_{2}$ for enhancing radiotherapy in hypoxic conditions. The as-designed MOF NPs were reported to effectively inhibit melanoma growth and prevent recurrence with only one X-ray irradiation after intravenous injection. Therefore, the nanosystem has great potential for overcoming the radioresistance challenge of hypoxic tumors.

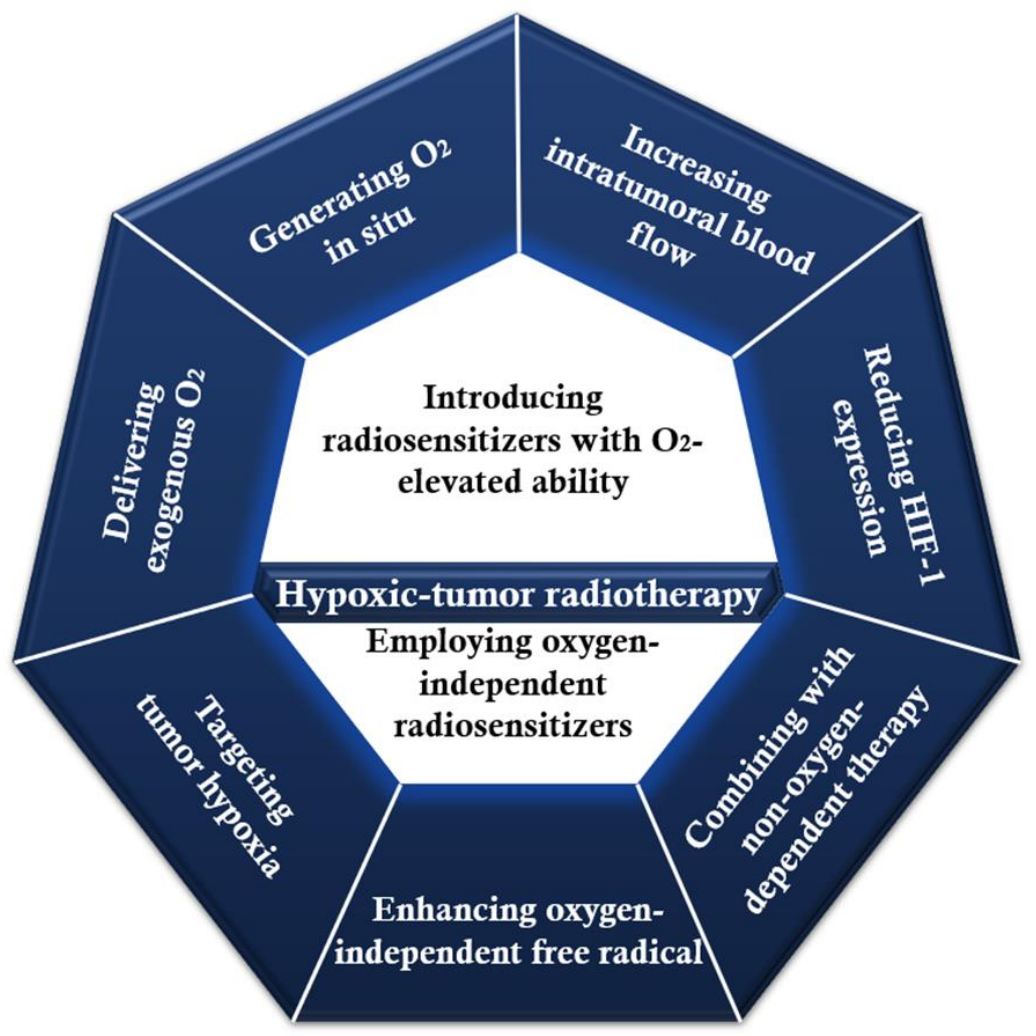

Figure 11. Potential strategies employing metal-based NPs for hypoxic-tumor radiotherapy. Created based on information from [170].

\subsection{Phototherapy}

Light has been long used for its healing potential in the treatment of various diseases. In the context of cancer treatment, two major therapeutic alternatives exploit light, namely photothermal therapy (PTT) and photodynamic therapy (PDT) [172]. These phototherapies attracted attention for various combinations with light-responsive or light-triggered NPs towards enhancing treatment efficiency and specificity [173].

PTT can be considered a form of ablative hyperthermia in which photothermal agents (PTAs) are used for the conversion of light into heat, resulting in the selective death of cancer cells under laser application [17]. More specifically, radiative excitation excites PTA, moving it to a higher level and resulting in thermal vibration emissions that kill tumor cells [174]. Therefore, tight control over temperature and temperature gradient is mandatory in order to avoid damaging surrounding normal tissues. Consequently, research started to focus on designing new nanostructures with optimized thermoplasmonic properties [22]. Particular 
attention has been drawn to Au NPs due to their SPR properties resulting from energy excitation achieved by irradiating them with specific wavelength light [16].

Nonetheless, recent studies also directed their investigations towards designing and evaluating PTAs made of other less-explored metal-based nanomaterials. For instance, Sharker and colleagues [175] reported the preparation of biocompatible tungsten oxide NPs functionalized with dopamine-conjugated hyaluronic acid. Under in vitro NIR irradiation, the particles displayed a rapid and significant rise in photothermal heat against MDAMB and A549 cancer cell lines, whereas in vivo studies proved long-term biocompatibility and efficient photothermal conversion with time-dependent tumor target accumulation. More recently, Sun et al. [176] developed tunable liquid metal nanoparticles with sphere-to-rod morphologies. Out of the tested shapes and compositions, gallium nanorods exhibited outstanding photothermal conversion efficiency and showed distinct temperature rise compared to gallium nanospheres and gallium-indicum alloy nanorods. These smart nanoliquid metals enhanced PTT in model animals, paving the way for further applications in tumor therapy and imaging. Alternatively, Yang et al. [177] have fabricated heterogeneous NPs with gallium-indicum alloy cores and metal shells (platinum, gold, silver, or copper). Particularly promising results have been obtained for GaIn@Pt NPs as they considerably increased photothermal conversion efficiency and improved thermal stability under NIR irradiation. These nanoconstructs also displayed a good Fenton-like catalytic effect, resulting in the conversion of endogenous tumor $\mathrm{H}_{2} \mathrm{O}_{2}$ into ROS. Moreover, NPs were further optimized by modification with polyethylene glycol, resulting in improved biocompatibility, efficient tumor homing after intravenous injection, and effective NIR-triggered photothermal-chemodynamic synergistic outcomes in a mouse tumor model.

PDT is another promising cancer treatment that can benefit from advancements in the field of metal-based NPs. PDT requires the use of light with specific wavelengths for the activation of photosensitive chemicals (known as photosensitizers PS) towards generation of ROS and further destruction of cancer cells. However, conventional PS may face a poor specific uptake in tumor cells, posing a threat on healthy neighboring tissues. Thus, involving nanotechnology in this type of therapy became fundamental for obtaining maximum results while avoiding side effects $[11,16,178]$.

In order to improve PS accumulation in the target tissue, these substances can be carried and delivered to the site by metal-based NPs. Compared to bare PS, such nanoplatforms exhibit long cycle time, slow degradation, and targeted and controlled release, benefiting also form enhanced permeability and retention effect [172]. Au NPs of many forms (e.g., nanocages, nanorods, nanoshells, and nanoclusters) can enhance PDT performance by sensitizing singlet oxygen formation, generating ROS, providing spatiotemporal control, and diminishing the undesirable effects of clinically used PS [16,179-181]. Titanium oxide has also attracted interest in PDT for treating malignant tumors, especially due to its adjustable bandgap, band position, and excellent photostability. Similarly, due to its electronic structure, zinc oxide has been investigated as a photo- or sonosensitizer for cancer therapy, displaying cytotoxic effects when exposed to appropriate external stimuli. Another metal derivative that has been demonstrated to be effective in PDT is manganese oxide. Manganese oxide-based nanoconstructs can generate $\mathrm{O}_{2}$ in situ by reacting with $\mathrm{H}_{2} \mathrm{O}_{2}$ from TME, while also consuming glutathione. Thus, it represents an interesting delivery vehicle for PSs, especially in hypoxic tumors [172,181,182].

\subsection{Diagnosis}

Early detection and thorough monitoring of cancer evolution are essential processes in controlling and preventing the disease [183]. Thus, despite advancements in various therapies, special focus is also required in developing more performant imaging and diagnosis modalities.

As there is only a low content of cancer biomarkers in the early phase of cancer, ultrasensitive and selective tools are mandatory for their detection. In this context, metal NPs have emerged as convenient solutions due to their unique optoelectronic properties 
and ease of functionalization. Materials such as gold, silver, and copper represent appealing candidates for developing analytical scaffolds, especially because their SPR bands are in the visible region. However, copper use is limited by its ease of oxidation, most of the studies involving $\mathrm{Au}$ and Ag-based nanoconstructs [184].

One innovative example of ultrasensitive surface-enhanced Raman scattering (SERS) immunoassay was recently developed by Yang et al. [183]. The scientists fabricated a core-shell nanostructure of $\mathrm{Au} @ \mathrm{Ag}$ that could detect $\alpha$-fetoprotein (AFP), a biomarker of liver cancer. The nanoplatform exhibited excellent analytical performance of the SERS immunoassay in the range from 0.5 to $100 \mathrm{pg} / \mathrm{mL}$ with a limit of detection of $0.081 \mathrm{pg} / \mathrm{mL}$ $(3 \sigma)$, demonstrating potential applications in clinical diagnosis.

\subsection{Imaging}

Interesting possibilities also arise from the use of Au NPs in the dual detection of prostate cancer via optical imaging (OI) and positron emission tomography (PET). In this respect, Pretze et al. [23] developed a complex nanosystem consisting of Au NPs decorated with a NIR dye and NODAGA chelator, which were further radio-labeled with ${ }^{64} \mathrm{Cu}$. The as-designed metal-based nanoplatform displayed favorable diagnostic properties concerning detection, biodistribution, and clearance, recommending these constructs for future therapeutic concepts.

Superparamagnetic iron oxide nanoparticles (SPIONs) represent another extensively researched metal derivative extensively studied for imaging applications. More specifically, SPIONs are investigated as contrast agents for visualizing tumors and metastatic cancer in different tissues, including the liver, spleen, and lymph nodes. SPIONs are attractive for such applications as they can reduce the relaxation time of the surrounding protons owing to their superparamagnetic behavior, being particularly suitable candidates for MRI [73].

\subsection{Theranostics}

In the continuous effort to create better tools for cancer management, multifunctional nanoparticles, called theranostics, emerged as performant alternatives to conventional therapeutics and imaging agents. Thus, numerous studies have recently investigated a myriad of nanomaterials that can encapsulate and co-deliver drugs, imaging moieties and genes, and even detect tumor cells by binding to specific receptors. In order to emphasize the developments encountered for metal-based NPs as theranostics, several examples have been gathered in Table 5 and Figure 12.

Table 5. Examples of recently developed metal-based theranostics.

\begin{tabular}{|c|c|c|c|c|c|c|}
\hline Material & Morphology & & Properties & & Observations & Ref. \\
\hline Silver & $\begin{array}{l}\text { Quasi-spherical } \\
\text { nanoparticles }\end{array}$ & घ & $\begin{array}{l}\text { Average size: }<50 \mathrm{~nm} \\
\text { Hydrodynamic } \\
\text { diameter: } \sim 95 \mathrm{~nm} \\
\text { Zeta potential: }-14 \mathrm{mV}\end{array}$ & $\begin{array}{l}\text {. } \\
\text {. } \\
\text { - }\end{array}$ & $\begin{array}{l}\text { NPs were biosynthesized using the leaf extract of } \\
\text { Zinnia elegans } \\
\text { No anticancer drug, targeting moiety, or fluorescent } \\
\text { molecule(s) were added to the NPs } \\
\text { Demonstrated anticancer activity in vitro } \\
\text { Illustrated NIR-based bioimaging when } \\
\text { intraperitoneally injected in C57BL6/J mice }\end{array}$ & [128] \\
\hline Silver & $\begin{array}{c}\text { Spherical and rod-like } \\
\text { nanoparticles }\end{array}$ & - & $\begin{array}{l}\text { Average size of NPs } \\
\text { obtained with ethylene } \\
\text { glycol: } 15.58 \pm 8.28 \mathrm{~nm} \\
\text { Average size of NPs } \\
\text { obtained with } \\
\text { tetraethylene glycol: } \\
72.44 \pm 21.82 \mathrm{~nm}\end{array}$ & ! & $\begin{array}{l}\text { NPs were stabilized with polyvinylpyrrolidone } \\
\text { NPs entered cancer cells, exhibiting intense green } \\
\text { fluorescence in tested cell lines (MCF-7 and U87-MG) } \\
\text { NPs efficiently internalized in tumor cells through } \\
\text { enhanced permeability and retention effect, without } \\
\text { causing hemolysis in red blood cells }\end{array}$ & [185] \\
\hline
\end{tabular}


Table 5. Cont.

\begin{tabular}{|c|c|c|c|c|c|c|}
\hline Material & Morphology & & Properties & & Observations & Ref. \\
\hline Iron oxide & $\begin{array}{l}\text { Nanospheres (coated } \\
\text { with boiling rice } \\
\text { starch extract) }\end{array}$ & $\begin{array}{l}\square \\
\square \\
\square \\
\square\end{array}$ & $\begin{array}{l}\text { Average size: } \\
86 \pm 3.6 \mathrm{~nm} \\
\text { Zeta potential: }-2.1 \mathrm{mV} \\
\text { (at } \mathrm{pH} 4.5),-4.2 \mathrm{mV} \text { (at } \\
\mathrm{pH} 7.2) \text {, and }-7.2 \mathrm{mV} \\
\text { (at } \mathrm{pH} 9.0) \\
\text { Saturation } \\
\text { magnetization: } \\
\sim 70.65 \text { emu/g } \\
\text { Drug loading: } \sim 78 \%\end{array}$ & $\begin{array}{l}\square \\
\square \\
\square\end{array}$ & $\begin{array}{l}\text { NPs were loaded with doxorubicin } \\
\text { Exhibited excellent photothermal stability, with a } \\
\text { high photothermal conversion efficiency } \\
\text { Showed high NIR absorption for photoacoustic } \\
\text { imaging-guided PTT } \\
\text { Doxorubicin was preferentially released at acidic } \\
\text { environment, specifically targeting cancer cells }\end{array}$ & [186] \\
\hline Iron oxide & $\begin{array}{l}\text { Nanospheres (coated } \\
\text { with porous calcium } \\
\text { phosphate) }\end{array}$ & - & $\begin{array}{l}\text { Size range: } 10-20 \mathrm{~nm} \\
\text { Relaxivity: } \\
845.71 \mathrm{mM}^{-1} \mathrm{~S}^{-1} \\
\text { Drug loading: } 89.6 \% \\
\text { after } 48 \mathrm{~h}\end{array}$ & $\begin{array}{l}\square \\
\square \\
\square\end{array}$ & $\begin{array}{l}\text { NPs were loaded with curcumin } \\
\text { Ensured a slow release of the anticancer agent } \\
\text { Strong shortening in the T2 relaxation time } \\
\text { Potential negative contrast agent for MRI }\end{array}$ & [187] \\
\hline Iron oxide & $\begin{array}{l}\text { Nanospheres (coated } \\
\text { with amorphous } \\
\text { silica) }\end{array}$ & $\begin{array}{l}\text { - } \\
\text { - } \\
\text { - }\end{array}$ & $\begin{array}{l}\text { Average diameter } \\
\text { (bimodal distribution): } \\
70.8 \pm 5.8 \text { and } \\
116.8 \pm 21.8 \mathrm{~nm} \\
\text { Saturation } \\
\text { magnetization: } 9 \mathrm{emu} / \mathrm{g} \\
\text { Drug loading: up to } 34 \% \\
\text { Specific absorption rate: } \\
24 \mathrm{~W} / \mathrm{g}\end{array}$ & - & $\begin{array}{l}\text { NPs were functionalized with curcuminoids } \\
\text { Good colloidal stability, dispersibility and magnetic } \\
\text { properties } \\
\text { Suitable for magnetic hyperthermia, fluorescence } \\
\text { imaging, and drug delivery }\end{array}$ & [188] \\
\hline $\begin{array}{l}\text { Gold-iron } \\
\text { oxide }\end{array}$ & $\begin{array}{l}\text { Core }\left(\mathrm{Fe}_{3} \mathrm{O}_{4}\right) \text {-shell } \\
(\mathrm{Au}) \text { structure }\end{array}$ & - & Size range: $5-10 \mathrm{~nm}$ & $\begin{array}{l}\square \\
\square \\
\square \\
\square\end{array}$ & $\begin{array}{l}\text { NPs induced ROS production } \\
\text { Efficiently internalized into PC } 3 \text { cells } \\
\text { Exhibited cytotoxicity in cancer cells under } \\
\text { X-ray radiations } \\
\text { Dose-dependent anticancer activity, reaching } \sim 95 \% \\
\text { cell deterioration for a concentration of } 20 \mu \mathrm{g} / \mathrm{mL} \\
\text { The specific accumulation of NPs in cancer cells } \\
\text { prevented destruction of healthy cells }\end{array}$ & [189] \\
\hline Iridium oxide & Sphere-like structure & ๘ & $\begin{array}{l}\text { Average diameter: } \\
30 \mathrm{~nm} \\
\text { Hydrodynamic } \\
\text { diameter: } \sim 55 \mathrm{~nm} \\
\text { Zeta potential: } \\
-0.407 \mathrm{mV}\end{array}$ & $\begin{array}{l}\mathbf{\square} \\
\mathbf{\square} \\
\mathbf{\square} \\
\mathbf{\square}\end{array}$ & $\begin{array}{l}\text { NPs were functionalized with split DNAzyme } \\
\text { precursor and doxorubicin } \\
\text { Fluorescence imaging studies proved the specificity } \\
\text { and feasibility of the NPs } \\
\text { Drug release was photothermally controlled } \\
\text { Excellent synergistic effects against cancer cells } \\
\text { under NIR } \\
\text { In vivo studies demonstrated great inhibition of } \\
\text { tumor growth }\end{array}$ & {$[190]$} \\
\hline $\begin{array}{l}\text { Copper(II) } \\
\text { diethyldithio- } \\
\text { carbamate } \\
\quad(\mathrm{CuET})\end{array}$ & $\begin{array}{l}\text { Complex loaded with } \\
\text { ultrasmall melanin } \\
\text { dots }\end{array}$ & ๘ & $\begin{array}{l}\text { Average size (of M-dots): } \\
\sim 8 \mathrm{~nm} \\
\text { Hydrodynamic } \\
\text { diameter (of M-dots): } \\
87.3 \pm 3.1 \mathrm{~nm} \\
\text { Zeta potential (of the } \\
\text { system): } 18 \mathrm{mV}\end{array}$ & $\begin{array}{l}\text { - } \\
\text { - } \\
\text { - }\end{array}$ & $\begin{array}{l}\text { Excellent biosafety and biocompatibility } \\
\text { CuET significantly enhanced the water solubility of } \\
\text { melanin dots } \\
\text { Good photoacoustic and chemo/photothermal } \\
\text { therapy properties } \\
\text { Good tumor accumulation and excellent tumor } \\
\text { proliferation inhibition } \\
\text { Combined with PTT, the nanosystem produced a } \\
\text { tumor growth inbition of } 78.6 \%\end{array}$ & [191] \\
\hline $\begin{array}{l}\text { Copper } \\
\text { sulfide }\end{array}$ & Nanospheres & - & $\begin{array}{l}\text { Average size: } \\
11.8 \pm 2.23 \mathrm{~nm} \\
\text { Longitudinal relaxivity: } \\
\text { up to } 12.9 \mathrm{mM}^{-1} \cdot \mathrm{s}^{-1} \\
\text { Zeta potential: } \\
-18.0 \pm 3.0 \mathrm{mV}\end{array}$ & $\begin{array}{l}\text { - } \\
\text { - } \\
\mathbf{\square}\end{array}$ & $\begin{array}{l}\text { NPs were surface-functionalized with gadolinium } \\
\text { and modified with folic acid (FA) } \\
\text { FA enabled NPs targeting, consequently enhancing } \\
\text { cellular uptake and therapy efficacy } \\
\text { The system integrates MR/IR dual-modal imaging } \\
\text { and PTT/PDT into one nanoplatform } \\
\text { Great potential in anti-breast cancer therapy }\end{array}$ & [192] \\
\hline $\begin{array}{c}\text { Bismuth } \\
\text { sulfide-gold }\end{array}$ & Nanospheres & ๘ & $\begin{array}{l}\text { Average size: } \\
\sim 8.5 \pm 3.0 \mathrm{~nm} \\
\text { Hydrodynamic } \\
\text { diameter: } \\
152.30 \pm 8.90 \mathrm{~nm} \\
\text { Zeta potential: } \\
-28.50 \mathrm{mV}\end{array}$ & $\begin{array}{l}\square \\
\text { घ } \\
\text { घ }\end{array}$ & $\begin{array}{l}\text { NPs were conjugated with methotrexate and } \\
\text { curcumin } \\
\text { Enhanced contrast of CT images } \\
\text { Increased free radical generation via the Schottky } \\
\text { barrier } \\
\text { Exhibited intrinsic radiosensitizing ability }\end{array}$ & [193] \\
\hline
\end{tabular}


(A)

(B)

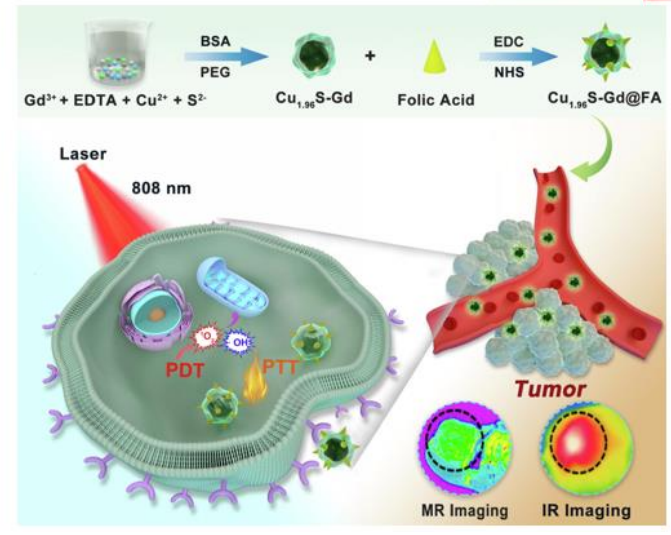

(C)

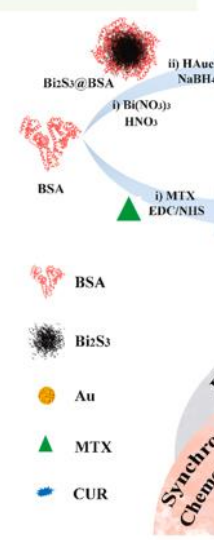

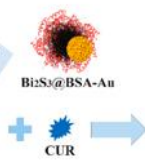

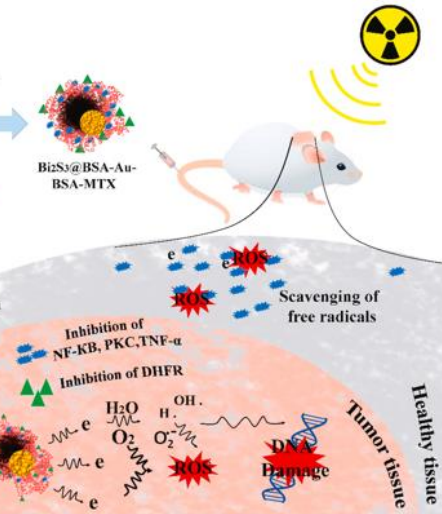

Figure 12. (A) Schematic representation of the synthesis of M-Dots-CuET and the process of PAIguided chemo/photothermal therapy using M-Dots-CuET. Reproduced with permission from [191], Elsevier B.V., 2021. (B) Schematic representation of the preparation of dual-modal MR/IR imagingguided synergistic PTT/PDT with Cu1.96S-Gd@FA nanoparticles. Reproduced with permission from [192], Elsevier B.V., 2022. (C) Schematic representation of the synthesis process and tumor ablation mechanism of Bi2S3@BSA-Au-BSA-MTX-CUR. Reproduced from [193], Elsevier B.V., 2022.

As described in Table 5, a variety of metal-based theranostics with different degrees of structural complexity and anticancer functionality has been tested. For instance, the simplest nanosystem included in the table (Ag NPs developed by Haque et al. [128]) required no anticancer drug, targeting moiety, or fluorescent molecule to work as an anticancer agent while also exhibiting NIR imaging potential. However, the encapsulation of various drugs (e.g., curcumin, melanin, doxorubicin, and methotrexate), the addition of different coatings (e.g., starch, calcium phosphate, and amorphous silica), and functionalization with certain biomolecules (e.g., folic acid, polyvinyl pyrrolidone, and split DNAzyme precursor) were demonstrated to significantly boost antitumor activity, ensuring specific targeting ability and controlled drug-release. Furthermore, these complex nanosystems allowed the simultaneous use of several approaches for fighting tumor growth. Specifically, there have been reported synergistic combinations integrating two or more of the following therapeutic and imaging modalities: chemotherapy, radiotherapy, PTT, PDT, magnetic hyperthermia, fluorescence imaging, MRI, NIR-based imaging, photoacoustic imaging, and CT imaging. Hence, metal-based theranostics have tremendous potential in developing highly performant chemotherapeutics, being expected to revolutionize cancer management in future years.

\section{Conclusions}

In summary, the development of metal nanoparticles is rapid and multidirectional, providing alternative treatment strategies and enhancing the outcomes of many cancer therapies. An increasing number of in vitro and in vivo studies has emerged in the specialty 
literature, showing promising results in the treatment of various cancers when using metalbased NPs with intrinsic anticancer properties or metallic nanoplatform in combinatorial approaches with other therapeutic options. In particular, the use of controlled-release systems triggered by $\mathrm{pH}$, temperature, electromagnetic waves, light, and enzymes brings critical precision to the delivery of chemotherapeutics, improving accumulation in tumor tissues and strengthening therapeutic results.

However, most metal-based formulations have not yet been translated to clinical settings, mainly due to toxicity concerns. The abilities of metallic NPs to generate ROS, induce oxidative stress, disturb cytoskeleton integrity, and damage DNA, which are the main reasons for choosing them as cytotoxic agents, also represent obstacles in their approval. Thus, it is important that future tests also focus on enhancing the biocompatibility of these platforms in healthy tissues, gathering more evidence on their safety profiles and long-term outcomes. Another significant concern related to metallic nanoparticles is their stability in biological media, which must be carefully tailored by using surface functionalization with various organic molecules, macromolecules, or noble metal coatings.

In conclusion, metal-based nanoconstructs hold great promise for developing more performant anticancer therapies, and they deserve further special interdisciplinary research efforts towards overcoming current limitations.

Author Contributions: All authors participated in the review, writing, and revision. All authors have read and agreed to the published version of the manuscript.

Funding: This research received no external funding.

Institutional Review Board Statement: Not applicable.

Informed Consent Statement: Not applicable.

Data Availability Statement: Not applicable.

Conflicts of Interest: The authors declare no conflict of interest.

\section{References}

1. Cordani, M.; Somoza, Á. Targeting autophagy using metallic nanoparticles: A promising strategy for cancer treatment. Cell. Mol. Life Sci. 2019, 76, 1215-1242. [CrossRef]

2. Chandra, H.; Kumari, P.; Bontempi, E.; Yadav, S. Medicinal plants: Treasure trove for green synthesis of metallic nanoparticles and their biomedical applications. Biocatal. Agric. Biotechnol. 2020, 24, 101518. [CrossRef]

3. Yew, Y.P.; Shameli, K.; Miyake, M.; Ahmad Khairudin, N.B.B.; Mohamad, S.E.B.; Naiki, T.; Lee, K.X. Green biosynthesis of superparamagnetic magnetite $\mathrm{Fe}_{3} \mathrm{O}_{4}$ nanoparticles and biomedical applications in targeted anticancer drug delivery system: A review. Arab. J. Chem. 2020, 13, 2287-2308. [CrossRef]

4. Mansouri, F. Role of Telemedicine and Telegenetics Framework for the Management of Cancer Patients During the COVID-19 Pandemic. Biointerface Res. Appl. Chem. 2021, 11, 8773-8779. [CrossRef]

5. Choi, J.; Kim, G.; Cho, S.B.; Im, H.-J. Radiosensitizing high-Z metal nanoparticles for enhanced radiotherapy of glioblastoma multiforme. J. Nanobiotechnol. 2020, 18, 122. [CrossRef]

6. Sharma, A.; Goyal, A.K.; Rath, G. Recent advances in metal nanoparticles in cancer therapy. J. Drug Target. 2018, 26, 617-632. [CrossRef]

7. Alromi, D.A.; Madani, S.Y.; Seifalian, A. Emerging Application of Magnetic Nanoparticles for Diagnosis and Treatment of Cancer. Polymers 2021, 13, 4146. [CrossRef]

8. Evans, E.R.; Bugga, P.; Asthana, V.; Drezek, R. Metallic nanoparticles for cancer immunotherapy. Mater. Today 2018, 21, 673-685. [CrossRef]

9. Jagaran, K.; Singh, M. Nanomedicine for COVID-19: Potential of Copper Nanoparticles. Biointerface Res. Appl. Chem. 2021, 11, 10716-10728. [CrossRef]

10. Hafeez, M.N.; Celia, C.; Petrikaite, V. Challenges towards Targeted Drug Delivery in Cancer Nanomedicines. Processes 2021, 9 , 1527. [CrossRef]

11. Shang, L.; Zhou, X.; Zhang, J.; Shi, Y.; Zhong, L. Metal Nanoparticles for Photodynamic Therapy: A Potential Treatment for Breast Cancer. Molecules 2021, 26, 6532. [CrossRef] [PubMed]

12. Tinajero-Díaz, E.; Salado-Leza, D.; Gonzalez, C.; Martínez Velázquez, M.; López, Z.; Bravo-Madrigal, J.; Knauth, P.; FloresHernández, F.Y.; Herrera-Rodríguez, S.E.; Navarro, R.E.; et al. Green Metallic Nanoparticles for Cancer Therapy: Evaluation Models and Cancer Applications. Pharmaceutics 2021, 13, 1719. [CrossRef] [PubMed] 
13. Penninckx, S.; Heuskin, A.-C.; Michiels, C.; Lucas, S. The role of thioredoxin reductase in gold nanoparticle radiosensitization effects. Nanomedicine 2018, 13, 2917-2937. [CrossRef] [PubMed]

14. Daems, N.; Penninckx, S.; Nelissen, I.; Van Hoecke, K.; Cardinaels, T.; Baatout, S.; Michiels, C.; Lucas, S.; Aerts, A. Gold nanoparticles affect the antioxidant status in selected normal human cells. Int. J. Nanomed. 2019, 14, 4991. [CrossRef]

15. Renitta, R.E.; Smitha, I.; Sahithya, C.S.; Samrot, A.V.; Abirami, S.; Dhiva, S.; Anand, D.A. Synthesis, Characterization, and Antibacterial Activity of Biosynthesized Gold Nanoparticles. Biointerface Res. Appl. Chem. 2021, 11, 9619-9628. [CrossRef]

16. Kang, M.S.; Lee, S.Y.; Kim, K.S.; Han, D.-W. State of the Art Biocompatible Gold Nanoparticles for Cancer Theragnosis Pharmaceutics 2020, 12, 701. [CrossRef]

17. Yang, W.; Liang, H.; Ma, S.; Wang, D.; Huang, J. Gold nanoparticle based photothermal therapy: Development and application for effective cancer treatment. Sustain. Mater. Technol. 2019, 22, e00109. [CrossRef]

18. Freitas de Freitas, L.; Varca, G.H.; Dos Santos Batista, J.G.; Benévolo Lugão, A. An Overview of the Synthesis of Gold Nanoparticles Using Radiation Technologies. Nanomaterials 2018, 8, 939. [CrossRef]

19. Aboyewa, J.A.; Sibuyi, N.R.S.; Meyer, M.; Oguntibeju, O.O. Green Synthesis of Metallic Nanoparticles Using Some Selected Medicinal Plants from Southern Africa and Their Biological Applications. Plants 2021, 10, 1929. [CrossRef]

20. Tripathy, A.; Behera, M.; Rout, A.S.; Biswal, S.K.; Phule, A.D. Optical, Structural, and Antimicrobial Study of Gold nanoparticles Synthesized Using an Aqueous Extract of Mimusops elengi Raw Fruits. Biointerface Res. Appl. Chem. 2020, 10, 7085-7096. [CrossRef]

21. Fan, M.; Han, Y.; Gao, S.; Yan, H.; Cao, L.; Li, Z.; Liang, X.-J.; Zhang, J. Ultrasmall gold nanoparticles in cancer diagnosis and therapy. Theranostics 2020, 10, 4944-4957. [CrossRef] [PubMed]

22. Szunerits, S.; Boukherroub, R. Near-Infrared Photothermal Heating with Gold Nanostructures. In Encyclopedia of Interfacial Chemistry; Wandelt, K., Ed.; Elsevier: Oxford, UK, 2018; pp. 500-510.

23. Pretze, M.; van der Meulen, N.P.; Wängler, C.; Schibli, R.; Wängler, B. Targeted 64Cu-labeled gold nanoparticles for dual imaging with positron emission tomography and optical imaging. J. Label. Compd. Radiopharm. 2019, 62, 471-482. [CrossRef] [PubMed]

24. Mikhailova, E.O. Gold Nanoparticles: Biosynthesis and Potential of Biomedical Application. J. Funct. Biomater. 2021, 12, 70. [CrossRef] [PubMed]

25. Li, L.; Zhang, W.; Desikan Seshadri, V.D.; Cao, G. Synthesis and characterization of gold nanoparticles from Marsdenia tenacissima and its anticancer activity of liver cancer HepG2 cells. Artif. Cells Nanomed. Biotechnol. 2019, 47, 3029-3036. [CrossRef]

26. Majumdar, M.; Biswas, S.C.; Choudhury, R.; Upadhyay, P.; Adhikary, A.; Roy, D.N.; Misra, T.K. Synthesis of Gold Nanoparticles Using Citrus macroptera Fruit Extract: Anti-Biofilm and Anticancer Activity. ChemistrySelect 2019, 4, 5714-5723. [CrossRef]

27. Zhang, X.; Tan, Z.; Jia, K.; Zhang, W.; Dang, M. Rabdosia rubescens Linn: Green synthesis of gold nanoparticles and their anticancer effects against human lung cancer cells A549. Artif. Cells Nanomed. Biotechnol. 2019, 47, 2171-2178. [CrossRef]

28. Sun, B.; Hu, N.; Han, L.; Pi, Y.; Gao, Y.; Chen, K. Anticancer activity of green synthesised gold nanoparticles from Marsdenia tenacissima inhibits A549 cell proliferation through the apoptotic pathway. Artif. Cells Nanomed. Biotechnol. 2019, 47, 4012-4019. [CrossRef]

29. Latha, D.; Prabu, P.; Arulvasu, C.; Manikandan, R.; Sampurnam, S.; Narayanan, V. Enhanced cytotoxic effect on human lung carcinoma cell line (A549) by gold nanoparticles synthesized from Justicia adhatoda leaf extract. Asian Pac. J. Trop. Biomed. 2018, 8,540 .

30. Chaturvedi, V.K.; Yadav, N.; Rai, N.K.; Ellah, N.H.A.; Bohara, R.A.; Rehan, I.F.; Marraiki, N.; Batiha, G.E.; Hetta, H.F.; Singh, M.P. Pleurotus sajor-caju-Mediated Synthesis of Silver and Gold Nanoparticles Active against Colon Cancer Cell Lines: A New Era of Herbonanoceutics. Molecules 2020, 25, 3091. [CrossRef]

31. Miri, A.; Darroudi, M.; Entezari, R.; Sarani, M. Biosynthesis of gold nanoparticles using Prosopis farcta extract and its in vitro toxicity on colon cancer cells. Res. Chem. Intermed. 2018, 44, 3169-3177. [CrossRef]

32. Han, X.; Jiang, X.; Guo, L.; Wang, Y.; Veeraraghavan, V.P.; Krishna Mohan, S.; Wang, Z.; Cao, D. Anticarcinogenic potential of gold nanoparticles synthesized from Trichosanthes kirilowii in colon cancer cells through the induction of apoptotic pathway. Artif. Cells Nanomed. Biotechnol. 2019, 47, 3577-3584. [CrossRef] [PubMed]

33. Wang, L.; Xu, J.; Yan, Y.; Liu, H.; Karunakaran, T.; Li, F. Green synthesis of gold nanoparticles from Scutellaria barbata and its anticancer activity in pancreatic cancer cell (PANC-1). Artif. Cells Nanomed. Biotechnol. 2019, 47, 1617-1627. [CrossRef] [PubMed]

34. Wang, L.; Xu, J.; Yan, Y.; Liu, H.; Li, F. Synthesis of gold nanoparticles from leaf Panax notoginseng and its anticancer activity in pancreatic cancer PANC-1 cell lines. Artif. Cells Nanomed. Biotechnol. 2019, 47, 1216-1223. [CrossRef] [PubMed]

35. Vemuri, S.K.; Banala, R.R.; Mukherjee, S.; Uppula, P.; Subbaiah, G.P.V.; AV, G.R.; Malarvilli, T. Novel biosynthesized gold nanoparticles as anti-cancer agents against breast cancer: Synthesis, biological evaluation, molecular modelling studies. Mater. Sci. Eng. C 2019, 99, 417-429. [CrossRef]

36. Singh, A.K.; Tiwari, R.; Singh, V.K.; Singh, P.; Khadim, S.R.; Singh, U.; Laxmi; Srivastava, V.; Hasan, S.H.; Asthana, R.K. Green synthesis of gold nanoparticles from Dunaliella salina, its characterization and in vitro anticancer activity on breast cancer cell line. J. Drug Deliv. Sci. Technol. 2019, 51, 164-176. [CrossRef]

37. Qian, L.; Su, W.; Wang, Y.; Dang, M.; Zhang, W.; Wang, C. Synthesis and characterization of gold nanoparticles from aqueous leaf extract of Alternanthera sessilis and its anticancer activity on cervical cancer cells (HeLa). Artif. Cells Nanomed. Biotechnol. 2019, 47, 1173-1180. [CrossRef] 
38. Khatua, A.; Prasad, A.; Priyadarshini, E.; Patel, A.K.; Naik, A.; Saravanan, M.; Barabadi, H.; Ghosh, 1.; Paul, B.; Paulraj, R.; et al. Emerging Antineoplastic Plant-Based Gold Nanoparticle Synthesis: A Mechanistic Exploration of their Anticancer Activity Toward Cervical Cancer Cells. J. Clust. Sci. 2020, 31, 1329-1340. [CrossRef]

39. Piktel, E.; Ościłowska, I.; Suprewicz, Ł.; Depciuch, J.; Marcińczyk, N.; Chabielska, E.; Wolak, P.; Wollny, T.; Janion, M.; ParlinskaWojtan, M.; et al. ROS-Mediated Apoptosis and Autophagy in Ovarian Cancer Cells Treated with Peanut-Shaped Gold Nanoparticles. Int. J. Nanomed. 2021, 16, 1993-2011. [CrossRef]

40. Abass Sofi, M.; Sunitha, S.; Ashaq Sofi, M.; Khadheer Pasha, S.K.; Choi, D. An overview of antimicrobial and anticancer potential of silver nanoparticles. J. King Saud Univ. Sci. 2022, 34, 101791. [CrossRef]

41. Burdușel, A.-C.; Gherasim, O.; Grumezescu, A.M.; Mogoantă, L.; Ficai, A.; Andronescu, E. Biomedical Applications of Silver Nanoparticles: An Up-to-Date Overview. Nanomaterials 2018, 8, 681. [CrossRef]

42. Gounden, S.; Daniels, A.; Singh, M. Chitosan-Modified Silver Nanoparticles Enhance Cisplatin Activity in Breast Cancer Cells. Biointerface Res. Appl. Chem. 2021, 11, 10572-10584. [CrossRef]

43. Mikhailova, E.O. Silver Nanoparticles: Mechanism of Action and Probable Bio-Application. J. Funct. Biomater. 2020, 11, 84. [CrossRef] [PubMed]

44. Miranda, R.R.; Sampaio, I.; Zucolotto, V. Exploring silver nanoparticles for cancer therapy and diagnosis. Colloids Surf. B Biointerfaces 2022, 210, 112254. [CrossRef] [PubMed]

45. Buttacavoli, M.; Albanese, N.N.; Di Cara, G.; Alduina, R.; Faleri, C.; Gallo, M.; Pizzolanti, G.; Gallo, G.; Feo, S.; Baldi, F.; et al Anticancer activity of biogenerated silver nanoparticles: An integrated proteomic investigation. Oncotarget 2017, 9, 9685-9705. [CrossRef]

46. Penninckx, S.; Heuskin, A.-C.; Michiels, C.; Lucas, S. Gold Nanoparticles as a Potent Radiosensitizer: A Transdisciplinary Approach from Physics to Patient. Cancers 2020, 12, 2021. [CrossRef]

47. Kankala, R.K.; Liu, C.-G.; Yang, D.-Y.; Wang, S.-B.; Chen, A.-Z. Ultrasmall platinum nanoparticles enable deep tumor penetration and synergistic therapeutic abilities through free radical species-assisted catalysis to combat cancer multidrug resistance. Chem. Eng. J. 2020, 383, 123138. [CrossRef]

48. Prakashkumar, N.; Vignesh, M.; Brindhadevi, K.; Phuong, N.T.; Pugazhendhi, A.; Suganthy, N. Enhanced antimicrobial, antibiofilm and anticancer activities of biocompatible neem gum coated palladium nanoparticles. Prog. Org. Coat. 2021, 151, 106098. [CrossRef]

49. Rahman, S.; Rahman, L.; Khalil, A.T.; Ali, N.; Zia, D.; Ali, M.; Shinwari, Z.K. Endophyte-mediated synthesis of silver nanoparticles and their biological applications. Appl. Microbiol. Biotechnol. 2019, 103, 2551-2569. [CrossRef]

50. Liao, C.; Li, Y.; Tjong, S.C. Bactericidal and Cytotoxic Properties of Silver Nanoparticles. Int. J. Mol. Sci. 2019, 20, 449. [CrossRef]

51. Das, G.; Patra, J.K.; Debnath, T.; Ansari, A.; Shin, H.-S. Investigation of antioxidant, antibacterial, antidiabetic, and cytotoxicity potential of silver nanoparticles synthesized using the outer peel extract of Ananas comosus (L.). PLoS ONE 2019, 14, e0220950.

52. Priya, K.; Vijayakumar, M.; Janani, B. Chitosan-mediated synthesis of biogenic silver nanoparticles (AgNPs), nanoparticle characterisation and in vitro assessment of anticancer activity in human hepatocellular carcinoma HepG2 cells. Int. J. Biol. Macromol. 2020, 149, 844-852. [CrossRef]

53. Ahmadian, E.; Dizaj, S.M.; Rahimpour, E.; Hasanzadeh, A.; Eftekhari, A.; Hosain Zadegan, H.; Halajzadeh, J.; Ahmadian, H. Effect of silver nanoparticles in the induction of apoptosis on human hepatocellular carcinoma (HepG2) cell line. Mater. Sci. Eng. C 2018, 93, 465-471. [CrossRef] [PubMed]

54. Khorrami, S.; Zarrabi, A.; Khaleghi, M.; Danaei, M.; Mozafari, M.R. Selective cytotoxicity of green synthesized silver nanoparticles against the MCF-7 tumor cell line and their enhanced antioxidant and antimicrobial properties. Int. J. Nanomed. 2018, 13, 8013. [CrossRef] [PubMed]

55. Gomathi, A.C.; Xavier Rajarathinam, S.R.; Mohammed Sadiq, A.; Rajeshkumar, S. Anticancer activity of silver nanoparticles synthesized using aqueous fruit shell extract of Tamarindus indica on MCF-7 human breast cancer cell line. J. Drug Deliv. Sci. Technol. 2020, 55, 101376. [CrossRef]

56. Dinparvar, S.; Bagirova, M.; Allahverdiyev, A.M.; Abamor, E.S.; Safarov, T.; Aydogdu, M.; Aktas, D. A nanotechnology-based new approach in the treatment of breast cancer: Biosynthesized silver nanoparticles using Cuminum cyminum L. seed extract. J. Photochem. Photobiol. B Biol. 2020, 208, 111902. [CrossRef]

57. Ebrahimzadeh, Z.; Salehzadeh, A.; Naeemi, A.S.; Jalali, A. Silver nanoparticles biosynthesized by Anabaena flos-aquae enhance the apoptosis in breast cancer cell line. Bull. Mater. Sci. 2020, 43, 92. [CrossRef]

58. Lakshmanan, G.; Sathiyaseelan, A.; Kalaichelvan, P.T.; Murugesan, K. Plant-mediated synthesis of silver nanoparticles using fruit extract of Cleome viscosa L.: Assessment of their antibacterial and anticancer activity. Karbala Int. J. Mod. Sci. 2018, 4, 61-68. [CrossRef]

59. Moldovan, B.; Sincari, V.; Perde-Schrepler, M.; David, L. Biosynthesis of Silver Nanoparticles Using Ligustrum Ovalifolium Fruits and Their Cytotoxic Effects. Nanomaterials 2018, 8, 627. [CrossRef]

60. Kumari, R.; Saini, A.K.; Kumar, A.; Saini, R.V. Apoptosis induction in lung and prostate cancer cells through silver nanoparticles synthesized from Pinus roxburghii bioactive fraction. JBIC J. Biol. Inorg. Chem. 2020, 25, 23-37. [CrossRef]

61. Chen, Y.; Yang, T.; Chen, S.; Qi, S.; Zhang, Z.; Xu, Y. Silver nanoparticles regulate autophagy through lysosome injury and cell hypoxia in prostate cancer cells. J. Biochem. Mol. Toxicol. 2020, 34, e22474. [CrossRef] 
62. Zhang, K.; Liu, X.; Samuel Ravi, S.O.A.; Ramachandran, A.; Aziz Ibrahim, I.A.; Nassir, A.M.; Yao, J. Synthesis of silver nanoparticles (AgNPs) from leaf extract of Salvia miltiorrhiza and its anticancer potential in human prostate cancer LNCaP cell lines. Artif. Cells Nanomed. Biotechnol. 2019, 47, 2846-2854. [CrossRef] [PubMed]

63. Dehghanizade, S.; Arasteh, J.; Mirzaie, A. Green synthesis of silver nanoparticles using Anthemis atropatana extract: Characterization and in vitro biological activities. Artif. Cells Nanomed. Biotechnol. 2018, 46, 160-168. [CrossRef] [PubMed]

64. Gurunathan, S.; Qasim, M.; Park, C.; Yoo, H.; Kim, J.-H.; Hong, K. Cytotoxic Potential and Molecular Pathway Analysis of Silver Nanoparticles in Human Colon Cancer Cells HCT116. Int. J. Mol. Sci. 2018, 19, 2269. [CrossRef] [PubMed]

65. Acharya, D.; Satapathy, S.; Somu, P.; Parida, U.K.; Mishra, G. Apoptotic Effect and Anticancer Activity of Biosynthesized Silver Nanoparticles from Marine Algae Chaetomorpha linum Extract Against Human Colon Cancer Cell HCT-116. Biol. Trace Elem. Res. 2021, 199, 1812-1822. [CrossRef]

66. Narasimha, V.R.; Latha, T.S.; Pallu, R.; Panati, K.; Narala, V.R. Anticancer Activities of Biogenic Silver Nanoparticles Targeting Apoptosis and Inflammatory Pathways in Colon Cancer Cells. J. Clust. Sci. 2021, 1-17. [CrossRef]

67. Kanipandian, N.; Li, D.; Kannan, S. Induction of intrinsic apoptotic signaling pathway in A549 lung cancer cells using silver nanoparticles from Gossypium hirsutum and evaluation of in vivo toxicity. Biotechnol. Rep. 2019, 23, e00339. [CrossRef]

68. Cyril, N.; George, J.B.; Joseph, L.; Raghavamenon, A.C.; VP, S. Assessment of antioxidant, antibacterial and anti-proliferative (lung cancer cell line A549) activities of green synthesized silver nanoparticles from Derris trifoliata. Toxicol. Res. 2019, 8, 297-308. [CrossRef]

69. Wen, X.; Wang, Q.; Dai, T.; Shao, J.; Wu, X.; Jiang, Z.; Jacob, J.A.; Jiang, C. Identification of possible reductants in the aqueous leaf extract of mangrove plant Rhizophora apiculata for the fabrication and cytotoxicity of silver nanoparticles against human osteosarcoma MG-63 cells. Mater. Sci. Eng. C 2020, 116, 111252. [CrossRef]

70. Michalakis, K.; Bakopoulou, A.; Papachristou, E.; Vasilaki, D.; Tsouknidas, A.; Michailidis, N.; Johnstone, E. Evaluation of the Response of HOS and Saos-2 Osteosarcoma Cell Lines When Exposed to Different Sizes and Concentrations of Silver Nanoparticles. BioMed Res. Int. 2021, 2021, 5013065. [CrossRef]

71. Pinel, S.; Thomas, N.; Boura, C.; Barberi-Heyob, M. Approaches to physical stimulation of metallic nanoparticles for glioblastoma treatment. Adv. Drug Deliv. Rev. 2019, 138, 344-357. [CrossRef]

72. Ramazanov, M.; Karimova, A.; Shirinova, H. Magnetism for Drug Delivery, MRI and Hyperthermia Applications: A Review. Biointerface Res. Appl. Chem. 2021, 11, 8654-8668. [CrossRef]

73. Chouhan, R.S.; Horvat, M.; Ahmed, J.; Alhokbany, N.; Alshehri, S.M.; Gandhi, S. Magnetic Nanoparticles-A Multifunctional Potential Agent for Diagnosis and Therapy. Cancers 2021, 13, 2213. [CrossRef] [PubMed]

74. Rasouli, R.; Gruttner, C.; Ardestani, M.S.; Faridi-Majidi, R. Preparation and Evaluation of New LAT1-Targeted USPION to Improve Sensitivity and Specificity in Metabolic Magnetic Imaging of Breast Cancer. Biointerface Res. Appl. Chem. 2021, 11, 10248-10264. [CrossRef]

75. Soetaert, F.; Korangath, P.; Serantes, D.; Fiering, S.; Ivkov, R. Cancer therapy with iron oxide nanoparticles: Agents of thermal and immune therapies. Adv. Drug Deliv. Rev. 2020, 163, 65-83. [CrossRef]

76. Turkbey, B.; Agarwal, H.K.; Shih, J.; Bernardo, M.; McKinney, Y.L.; Daar, D.; Griffiths, G.L.; Sankineni, S.; Johnson, L.; Grant, K.B.; et al. A Phase I Dosing Study of Ferumoxytol for MR Lymphography at 3 T in Patients With Prostate Cancer. AJR Am. J. Roentgenol. 2015, 205, 64-69. [CrossRef]

77. Ag, M. The NanoTherm ${ }^{\circledR T}$ Therapy in Detail. Available online: https://www.magforce.com/en/home/for_patients/ (accessed on 7 February 2022).

78. Ma, D.; Shi, M.; Li, X.; Zhang, J.; Fan, Y.; Sun, K.; Jiang, T.; Peng, C.; Shi, X. Redox-Sensitive Clustered Ultrasmall Iron Oxide Nanoparticles for Switchable T2/T1-Weighted Magnetic Resonance Imaging Applications. Bioconjugate Chem. 2019, 31, 352-359. [CrossRef]

79. Chen, W.; Yang, Z. Human gastric carcinoma cells targeting peptide-functionalized iron oxide nanoparticles delivery for magnetic resonance imaging. Process Biochem. 2020, 99, 171-178. [CrossRef]

80. Shen, C.; Wang, X.; Zheng, Z.; Gao, C.; Chen, X.; Zhao, S.; Dai, Z. Doxorubicin and indocyanine green loaded superparamagnetic iron oxide nanoparticles with PEGylated phospholipid coating for magnetic resonance with fluorescence imaging and chemotherapy of glioma. Int. J. Nanomed. 2019, 14, 101. [CrossRef]

81. Wang, P.; Sun, W.; Guo, J.; Zhang, K.; Liu, Y.; Jiang, Q.; Su, D.; Sun, X. One pot synthesis of zwitteronic 99mTc doped ultrasmall iron oxide nanoparticles for SPECT/T1-weighted MR dual-modality tumor imaging. Colloids Surf. B Biointerfaces 2021, 197, 111403. [CrossRef]

82. Chung, I.J.; Jeon, S.I.; Cha, E.-J.; Byun, Y.; Kwon, I.C.; Kim, Y.I.; Kim, K.; Ahn, C.-H. Activatable NIRF/MRI dual imaging probe using bio-inspired coating of glycol chitosan on superparamagnetic iron oxide nanoparticles. J. Ind. Eng. Chem. 2019, 76, 403-409. [CrossRef]

83. Aslam, H.; Shukrullah, S.; Naz, M.Y.; Fatima, H.; Hussain, H.; Ullah, S.; Assiri, M.A. Current and future perspectives of multifunctional magnetic nanoparticles based controlled drug delivery systems. J. Drug Deliv. Sci. Technol. 2022, 67, 102946. [CrossRef]

84. Mu, Q.; Lin, G.; Jeon, M.; Wang, H.; Chang, F.-C.; Revia, R.A.; Yu, J.; Zhang, M. Iron oxide nanoparticle targeted chemoimmunotherapy for triple negative breast cancer. Mater. Today 2021, 50, 149-169. [CrossRef] [PubMed] 
85. Panda, J.; Satapathy, B.S.; Majumder, S.; Sarkar, R.; Mukherjee, B.; Tudu, B. Engineered polymeric iron oxide nanoparticles as potential drug carrier for targeted delivery of docetaxel to breast cancer cells. J. Magn. Magn. Mater. 2019, 485, 165-173. [CrossRef]

86. Das, S.; Diyali, S.; Vinothini, G.; Perumalsamy, B.; Balakrishnan, G.; Ramasamy, T.; Dharumadurai, D.; Biswas, B. Synthesis, morphological analysis, antibacterial activity of iron oxide nanoparticles and the cytotoxic effect on lung cancer cell line. Heliyon 2020, 6, e04953. [CrossRef]

87. Shi, Z.; Mahdavian, Y.; Mahdavian, Y.; Mahdigholizad, S.; Irani, P.; Karimian, M.; Abbasi, N.; Ghaneialvar, H.; Zangeneh, A.; Mahdi Zangeneh, M. Cu immobilized on chitosan-modified iron oxide magnetic nanoparticles: Preparation, characterization and investigation of its anti-lung cancer effects. Arab. J. Chem. 2021, 14, 103224. [CrossRef]

88. Khan, S.; Setua, S.; Kumari, S.; Dan, N.; Massey, A.; Hafeez, B.B.; Yallapu, M.M.; Stiles, Z.E.; Alabkaa, A.; Yue, J.; et al. Superparamagnetic iron oxide nanoparticles of curcumin enhance gemcitabine therapeutic response in pancreatic cancer. Biomaterials 2019, 208, 83-97. [CrossRef]

89. Sakthi Sri, S.P.; Taj, J.; George, M. Facile synthesis of magnetite nanocubes using deep eutectic solvent: An insight to anticancer and photo-Fenton efficacy. Surf. Interfaces 2020, 20, 100609. [CrossRef]

90. Shi, Y.; Wang, J.; Liu, J.; Lin, G.; Xie, F.; Pang, X.; Pei, Y.; Cheng, Y.; Zhang, Y.; Lin, Z.; et al. Oxidative stress-driven DR5 upregulation restores TRAIL/Apo2L sensitivity induced by iron oxide nanoparticles in colorectal cancer. Biomaterials 2020, 233, 119753. [CrossRef]

91. Youhannayee, M.; Nakhaei-Rad, S.; Haghighi, F.; Klauke, K.; Janiak, C.; Ahmadian, M.R.; Rabenalt, R.; Albers, P.; Getzlaff, M. Physical characterization and uptake of iron oxide nanoparticles of different prostate cancer cells. J. Magn. Magn. Mater. 2019, 473, 205-214. [CrossRef]

92. Krais, A.; Wortmann, L.; Hermanns, L.; Feliu, N.; Vahter, M.; Stucky, S.; Mathur, S.; Fadeel, B. Targeted uptake of folic acidfunctionalized iron oxide nanoparticles by ovarian cancer cells in the presence but not in the absence of serum. Nanomed. Nanotechnol. Biol. Med. 2014, 10, 1421-1431. [CrossRef]

93. Wiesmann, N.; Tremel, W.; Brieger, J. Zinc oxide nanoparticles for therapeutic purposes in cancer medicine. J. Mater. Chem. B 2020, 8, 4973-4989. [CrossRef] [PubMed]

94. Droepenu, E.K.; Asare, E.A.; Dampare, S.B.; Adotey, D.K.; Gyampoh, A.O.; Kumi-Arhin, E. Laboratory and Commercial Synthesized Zinc Oxide Nanoparticles Adsorption onto Coconut Husk: Characterization, Isotherm, Kinetic, and Thermodynamic Studies. Biointerface Res. Appl. Chem. 2021, 11, 7871-7889. [CrossRef]

95. Majeed, S.; Danish, M.; Ismail, M.H.B.; Ansari, M.T.; Ibrahim, M.N.M. Anticancer and apoptotic activity of biologically synthesized zinc oxide nanoparticles against human colon cancer HCT-116 cell line- in vitro study. Sustain. Chem. Pharm. 2019, 14, 100179. [CrossRef]

96. Norouzi Jobie, F.; Ranjbar, M.; Hajizadeh Moghaddam, A.; Kiani, M. Green synthesis of zinc oxide nanoparticles using Amygdalus scoparia Spach stem bark extract and their applications as an alternative antimicrobial, anticancer, and anti-diabetic agent. Adv. Powder Technol. 2021, 32, 2043-2052. [CrossRef]

97. Zhang, H.; Liang, Z.; Zhang, J.; Wang, W.-p.; Zhang, H.; Lu, Q. Zinc oxide nanoparticle synthesized from Euphorbia fischeriana root inhibits the cancer cell growth through modulation of apoptotic signaling pathways in lung cancer cells. Arab. J. Chem. 2020, 13, 6174-6183. [CrossRef]

98. Rajeshkumar, S.; Kumar, S.V.; Ramaiah, A.; Agarwal, H.; Lakshmi, T.; Roopan, S.M. Biosynthesis of zinc oxide nanoparticles usingMangifera indica leaves and evaluation of their antioxidant and cytotoxic properties in lung cancer (A549) cells. Enzym. Microb. Technol. 2018, 117, 91-95. [CrossRef] [PubMed]

99. Wang, Y.; Zhang, Y.; Guo, Y.; Lu, J.; Veeraraghavan, V.P.; Mohan, S.K.; Wang, C.; Yu, X. Synthesis of Zinc oxide nanoparticles from Marsdenia tenacissima inhibits the cell proliferation and induces apoptosis in laryngeal cancer cells (Hep-2). J. Photochem. Photobiol. B Biol. 2019, 201, 111624. [CrossRef]

100. Cheng, J.; Wang, X.; Qiu, L.; Li, Y.; Marraiki, N.; Elgorban, A.M.; Xue, L. Green synthesized zinc oxide nanoparticles regulates the apoptotic expression in bone cancer cells MG-63 cells. J. Photochem. Photobiol. B Biol. 2020, 202, 111644. [CrossRef]

101. Jayakodi, S.; Shanmugam, V.K. Green Synthesis of CuO Nanoparticles and its Application on Toxicology Evaluation. Biointerface Res. Appl. Chem. 2020, 10, 6343-6353. [CrossRef]

102. Mani, V.M.; Kalaivani, S.; Sabarathinam, S.; Vasuki, M.; Soundari, A.J.P.G.; Ayyappa Das, M.P.; Elfasakhany, A.; Pugazhendhi, A. Copper oxide nanoparticles synthesized from an endophytic fungus Aspergillus terreus: Bioactivity and anti-cancer evaluations. Environ. Res. 2021, 201, 111502. [CrossRef]

103. Gnanavel, V.; Palanichamy, V.; Roopan, S.M. Biosynthesis and characterization of copper oxide nanoparticles and its anticancer activity on human colon cancer cell lines (HCT-116). J. Photochem. Photobiol. B Biol. 2017, 171, 133-138. [CrossRef] [PubMed]

104. Zou, X.; Cheng, S.; You, B.; Yang, C. Bio-mediated synthesis of copper oxide nanoparticles using Pogestemon benghalensis extract for treatment of the esophageal cancer in nursing care. J. Drug Deliv. Sci. Technol. 2020, 58, 101759. [CrossRef]

105. Fahmy, H.M.; Ebrahim, N.M.; Gaber, M.H. In-vitro evaluation of copper/copper oxide nanoparticles cytotoxicity and genotoxicity in normal and cancer lung cell lines. J. Trace Elem. Med. Biol. 2020, 60, 126481. [CrossRef] [PubMed]

106. Biresaw, S.S.; Taneja, P. Copper nanoparticles green synthesis and characterization as anticancer potential in breast cancer cells (MCF7) derived from Prunus nepalensis phytochemicals. Mater. Today Proc. 2022, 49, 3501-3509. [CrossRef]

107. Nagajyothi, P.C.; Muthuraman, P.; Sreekanth, T.V.M.; Kim, D.H.; Shim, J. Green synthesis: In-vitro anticancer activity of copper oxide nanoparticles against human cervical carcinoma cells. Arab. J. Chem. 2017, 10, 215-225. [CrossRef] 
108. Yang, Q.; Wang, Y.; Yang, Q.; Gao, Y.; Duan, X.; Fu, Q.; Chu, C.; Pan, X.; Cui, X.; Sun, Y. Cuprous oxide nanoparticles trigger ER stress-induced apoptosis by regulating copper trafficking and overcoming resistance to sunitinib therapy in renal cancer. Biomaterials 2017, 146, 72-85. [CrossRef] [PubMed]

109. Mukhopadhyay, R.; Kazi, J.; Debnath, M.C. Synthesis and characterization of copper nanoparticles stabilized with Quisqualis indica extract: Evaluation of its cytotoxicity and apoptosis in B16F10 melanoma cells. Biomed. Pharmacother. 2018, 97, 1373-1385. [CrossRef]

110. Vigneshwaran, R.; Ezhilarasan, D.; Rajeshkumar, S. Inorganic titanium dioxide nanoparticles induces cytotoxicity in colon cancer cells. Inorg. Chem. Commun. 2021, 133, 108920. [CrossRef]

111. Kim, H.; Jeon, D.; Oh, S.; Nam, K.; Son, S.; Gye, M.C.; Shin, I. Titanium dioxide nanoparticles induce apoptosis by interfering with EGFR signaling in human breast cancer cells. Environ. Res. 2019, 175, 117-123. [CrossRef]

112. Ai, J.-w.; Liu, B.; Liu, W.-d. Folic acid-tagged titanium dioxide nanoparticles for enhanced anticancer effect in osteosarcoma cells. Mater. Sci. Eng. C 2017, 76, 1181-1187. [CrossRef]

113. Nazaripour, E.; Mousazadeh, F.; Doosti Moghadam, M.; Najafi, K.; Borhani, F.; Sarani, M.; Ghasemi, M.; Rahdar, A.; Iravani, S.; Khatami, M. Biosynthesis of lead oxide and cerium oxide nanoparticles and their cytotoxic activities against colon cancer cell line. Inorg. Chem. Commun. 2021, 131, 108800. [CrossRef]

114. Vassie, J.A.; Whitelock, J.M.; Lord, M.S. Endocytosis of cerium oxide nanoparticles and modulation of reactive oxygen species in human ovarian and colon cancer cells. Acta Biomater. 2017, 50, 127-141. [CrossRef] [PubMed]

115. Wason, M.S.; Colon, J.; Das, S.; Seal, S.; Turkson, J.; Zhao, J.; Baker, C.H. Sensitization of pancreatic cancer cells to radiation by cerium oxide nanoparticle-induced ROS production. Nanomed. Nanotechnol. Biol. Med. 2013, 9, 558-569. [CrossRef]

116. Do, M.; Stinson, K.; George, R. Reflectance structured illumination imaging of internalized cerium oxide nanoparticles modulating dose-dependent reactive oxygen species in breast cancer cells. Biochem. Biophys. Rep. 2020, 22, 100745. [CrossRef] [PubMed]

117. Sridharan, M.; Kamaraj, P.; Vennilaraj; Arockiaselvi, J.; Pushpamalini, T.; Vivekanand, P.A.; Hari Kumar, S. Synthesis, characterization and evaluation of biosynthesized Cerium oxide nanoparticle for its anticancer activity on breast cancer cell (MCF 7). Mater. Today Proc. 2021, 36, 914-919. [CrossRef]

118. Piermatti, O. Green Synthesis of Pd Nanoparticles for Sustainable and Environmentally Benign Processes. Catalysts 2021, 11, 1258. [CrossRef]

119. Bangde, P.; Pant, T.; Gaikwad, G.; Jain, R.; Dandekar, P. Trimethyl chitosan coated palladium nanoparticles as a photothermal agent and its in vitro evaluation in 2D and 3D model of breast cancer cells. Colloids Surf. B Biointerfaces 2022, $211,112287$. [CrossRef]

120. Gurunathan, S.; Qasim, M.; Park, C.H.; Arsalan Iqbal, M.; Yoo, H.; Hwang, J.H.; Uhm, S.J.; Song, H.; Park, C.; Choi, Y.; et al. Cytotoxicity and Transcriptomic Analyses of Biogenic Palladium Nanoparticles in Human Ovarian Cancer Cells (SKOV3). Nanomaterials 2019, 9, 787. [CrossRef]

121. He, J.; Wang, J.; Gao, S.; Cui, Y.; Ji, X.; Zhang, X.; Wang, L. Biomineralized synthesis of palladium nanoflowers for photothermal treatment of cancer and wound healing. Int. J. Pharm. 2022, 121489. [CrossRef]

122. Jan, H.; Gul, R.; Andleeb, A.; Ullah, S.; Shah, M.; Khanum, M.; Ullah, I.; Hano, C.; Abbasi, B.H. A detailed review on biosynthesis of platinum nanoparticles (PtNPs), their potential antimicrobial and biomedical applications. J. Saudi Chem. Soc. 2021, $25,101297$. [CrossRef]

123. Khan, M.A.R.; Mamun, M.S.A.; Ara, M.H. Review on platinum nanoparticles: Synthesis, characterization, and applications. Microchem. J. 2021, 171, 106840. [CrossRef]

124. Hosny, M.; Fawzy, M.; El-Fakharany, E.M.; Omer, A.M.; El-Monaem, E.M.A.; Khalifa, R.E.; Eltaweil, A.S. Biogenic synthesis, characterization, antimicrobial, antioxidant, antidiabetic, and catalytic applications of platinum nanoparticles synthesized from Polygonum salicifolium leaves. J. Environ. Chem. Eng. 2022, 10, 106806. [CrossRef]

125. Tarkistani, M.A.M.; Komalla, V.; Kayser, V. Recent Advances in the Use of Iron-Gold Hybrid Nanoparticles for Biomedical Applications. Nanomaterials 2021, 11, 1227. [CrossRef] [PubMed]

126. Pan, Y.; Xue, P.; Liu, S.; Zhang, L.; Guan, Q.; Zhu, J.; Tian, X. Metal-Based Hybrid Nanoparticles as Radiosensitizers in Cancer Therapy. Colloid Interface Sci. Commun. 2018, 23, 45-51. [CrossRef]

127. Huynh, K.-H.; Pham, X.-H.; Kim, J.; Lee, S.H.; Chang, H.; Rho, W.-Y.; Jun, B.-H. Synthesis, Properties, and Biological Applications of Metallic Alloy Nanoparticles. Int. J. Mol. Sci. 2020, 21, 5174. [CrossRef] [PubMed]

128. Haque, S.; Norbert, C.C.; Acharyya, R.; Mukherjee, S.; Kathirvel, M.; Patra, C.R. Biosynthesized Silver Nanoparticles for Cancer Therapy and In Vivo Bioimaging. Cancers 2021, 13, 6114. [CrossRef]

129. Rahman, M.; Alam, K.; Hafeez, A.; Ilyas, R.; Beg, S. Chapter 7-Metallic nanoparticles in drug delivery and cancer treatment. In Nanoformulation Strategies for Cancer Treatment; Beg, S., Rahman, M., Choudhry, H., Souto, E.B., Ahmad, F.J., Eds.; Elsevier: Amsterdam, The Netherlands, 2021; pp. 107-119.

130. Gandhi, S.; Shende, P. Cyclodextrins-modified metallic nanoparticles for effective cancer therapy. J. Control. Release 2021, 339, 41-50. [CrossRef]

131. Al-Dulimi, A.G.; Al-Saffar, A.Z.; Sulaiman, G.M.; Khalil, K.A.A.; Khashan, K.S.; Al-Shmgani, H.S.A.; Ahmed, E.M. Immobilization of l-asparaginase on gold nanoparticles for novel drug delivery approach as anti-cancer agent against human breast carcinoma cells. J. Mater. Res. Technol. 2020, 9, 15394-15411. [CrossRef] 
132. Danışman-Kalındemirtaş, F.; Kariper, İ.A.; Hepokur, C.; Erdem-Kuruca, S. Selective cytotoxicity of paclitaxel bonded silver nanoparticle on different cancer cells. J. Drug Deliv. Sci. Technol. 2021, 61, 102265. [CrossRef]

133. Gul, A.R.; Shaheen, F.; Rafique, R.; Bal, J.; Waseem, S.; Park, T.J. Grass-mediated biogenic synthesis of silver nanoparticles and their drug delivery evaluation: A biocompatible anti-cancer therapy. Chem. Eng. J. 2021, 407, 127202. [CrossRef]

134. Ebadi, M.; Buskaran, K.; Bullo, S.; Hussein, M.Z.; Fakurazi, S.; Pastorin, G. Drug delivery system based on magnetic iron oxide nanoparticles coated with (polyvinyl alcohol-zinc/aluminium-layered double hydroxide-sorafenib). Alex. Eng. J. 2021, 60, 733-747. [CrossRef]

135. Mdlovu, N.V.; Lin, K.-S.; Weng, M.-T.; Lin, Y.-S. Design of doxorubicin encapsulated pH-/thermo-responsive and cationic shell-crosslinked magnetic drug delivery system. Colloids Surf. B Biointerfaces 2022, 209, 112168. [CrossRef] [PubMed]

136. Li, S.; Zhang, R.; Wang, D.; Feng, L.; Cui, K. Synthesis of hollow maghemite $\left(\gamma-\mathrm{Fe}_{2} \mathrm{O}_{3}\right)$ particles for magnetic field and pHresponsive drug delivery and lung cancer treatment. Ceram. Int. 2021, 47, 7457-7464. [CrossRef]

137. Binu, N.M.; Prema, D.; Prakash, J.; Balagangadharan, K.; Balashanmugam, P.; Selvamurugan, N.; Venkatasubbu, G.D. Folic acid decorated $\mathrm{pH}$ sensitive polydopamine coated honeycomb structured nickel oxide nanoparticles for targeted delivery of quercetin to triple negative breast cancer cells. Colloids Surf. A Physicochem. Eng. Asp. 2021, 630, 127609. [CrossRef]

138. Sathishkumar, P.; Li, Z.; Govindan, R.; Jayakumar, R.; Wang, C.; Long Gu, F. Zinc oxide-quercetin nanocomposite as a smart nano-drug delivery system: Molecular-level interaction studies. Appl. Surf. Sci. 2021, 536, 147741. [CrossRef]

139. Ghanbari, M.; Davar, F.; Shalan, A.E. Effect of rosemary extract on the microstructure, phase evolution, and magnetic behavior of cobalt ferrite nanoparticles and its application on anti-cancer drug delivery. Ceram. Int. 2021, 47, 9409-9417. [CrossRef]

140. Mohammadhassan, Z.; Mohammadkhani, R.; Mohammadi, A.; Zaboli, K.A.; Kaboli, S.; Rahimi, H.; Nosrati, H.; Danafar, H Preparation of copper oxide nanoparticles coated with bovine serum albumin for delivery of methotrexate. J. Drug Deliv. Sci. Technol. 2022, 67, 103015. [CrossRef]

141. Liu, C.; Li, M.; Li, P.; Chen, W.; Li, H.; Fan, L.; Tian, W. Platinum-Containing Supramolecular Drug Self-Delivery Nanomicelles for Efficient Synergistic Combination Chemotherapy. Biomacromolecules 2021, 22, 2382-2392. [CrossRef]

142. Mazidi, Z.; Javanmardi, S.; Naghib, S.M.; Mohammadpour, Z. Smart stimuli-responsive implantable drug delivery systems for programmed and on-demand cancer treatment: An overview on the emerging materials. Chem. Eng. J. 2022, 433, 134569. [CrossRef]

143. Ge, J.; Zhang, Y.; Dong, Z.; Jia, J.; Zhu, J.; Miao, X.; Yan, B. Initiation of Targeted Nanodrug Delivery in Vivo by a Multifunctional Magnetic Implant. ACS Appl. Mater. Interfaces 2017, 9, 20771-20778. [CrossRef]

144. Li, J.; Ren, H.; Zhang, Y. Metal-based nano-vaccines for cancer immunotherapy. Coord. Chem. Rev. 2022, 455, 214345. [CrossRef]

145. Wen, R.; Umeano, A.C.; Kou, Y.; Xu, J.; Farooqi, A.A. Nanoparticle systems for cancer vaccine. Nanomedicine 2019, 14, 627-648. [CrossRef] [PubMed]

146. Tornesello, A.L.; Tagliamonte, M.; Tornesello, M.L.; Buonaguro, F.M.; Buonaguro, L. Nanoparticles to Improve the Efficacy of Peptide-Based Cancer Vaccines. Cancers 2020, 12, 1049. [CrossRef] [PubMed]

147. Firdaus, F.Z.; Skwarczynski, M.; Toth, I. Developments in Vaccine Adjuvants. In Vaccine Design. Methods in Molecular Biology; Humana: New York, NY, USA, 2022; pp. 145-178.

148. Dong, H.; Wen, Z.-F.; Chen, L.; Zhou, N.; Liu, H.; Dong, S.; Hu, H.-m.; Mou, Y. Polyethyleneimine modification of aluminum hydroxide nanoparticle enhances antigen transportation and cross-presentation of dendritic cells. Int. J. Nanomed. 2018, 13, 3353. [CrossRef] [PubMed]

149. Zhao, Y.; Zhao, X.; Cheng, Y.; Guo, X.; Yuan, W. Iron Oxide Nanoparticles-Based Vaccine Delivery for Cancer Treatment. Mol. Pharm. 2018, 15, 1791-1799. [CrossRef] [PubMed]

150. Wang, B.; An, J.; Zhang, H.; Zhang, S.; Zhang, H.; Wang, L.; Zhang, H.; Zhang, Z. Personalized Cancer Immunotherapy via Transporting Endogenous Tumor Antigens to Lymph Nodes Mediated by Nano Fe $\mathrm{O}_{4}$. Small 2018, 14, 1801372. [CrossRef]

151. Afroz, S.; Medhi, H.; Maity, S.; Minhas, G.; Battu, S.; Giddaluru, J.; Kumar, K.; Paik, P.; Khan, N. Mesoporous ZnO nanocapsules for the induction of enhanced antigen-specific immunological responses. Nanoscale 2017, 9, 14641-14653. [CrossRef]

152. Sharma, P.; Shin, J.B.; Park, B.C.; Lee, J.-W.; Byun, S.W.; Jang, N.-Y.; Kim, Y.J.; Kim, Y.; Kim, Y.K.; Cho, N.-H. Application of radially grown $\mathrm{ZnO}$ nanowires on poly-l-lactide microfibers complexed with a tumor antigen for cancer immunotherapy. Nanoscale 2019, 11, 4591-4600. [CrossRef]

153. Zhang, L.-x.; Xie, X.-x.; Liu, D.-q.; Xu, Z.P.; Liu, R.-t. Efficient co-delivery of neo-epitopes using dispersion-stable layered double hydroxide nanoparticles for enhanced melanoma immunotherapy. Biomaterials 2018, 174, 54-66. [CrossRef]

154. Goodwin, T.J.; Huang, L. Investigation of phosphorylated adjuvants co-encapsulated with a model cancer peptide antigen for the treatment of colorectal cancer and liver metastasis. Vaccine 2017, 35, 2550-2557. [CrossRef]

155. Sharma, S.K.; Shrivastava, N.; Rossi, F.; Tung, L.D.; Thanh, N.T.K. Nanoparticles-based magnetic and photo induced hyperthermia for cancer treatment. Nano Today 2019, 29, 100795. [CrossRef]

156. Mallory, M.; Gogineni, E.; Jones, G.C.; Greer, L.; Simone, C.B. Therapeutic hyperthermia: The old, the new, and the upcoming. Crit. Rev. Oncol. Hematol. 2016, 97, 56-64. [CrossRef] [PubMed]

157. Zuo, X.; Ding, H.; Zhang, J.; Fang, T.; Zhang, D. Carbothermal treated iron oxide nanoparticles with improving magnetic heating efficiency for hyperthermia. Results Phys. 2022, 32, 105095. [CrossRef]

158. Ohannesian, N.; De Leo, C.T.; Martirosyan, K.S. Dextran coated superparamagnetic iron oxide nanoparticles produced by microfluidic process. Mater. Today Proc. 2019, 13, 397-403. [CrossRef] 
159. Shatooti, S.; Mozaffari, M.; Reiter, G.; Zahn, D.; Dutz, S. An investigation on the heat dissipation in Zn-substituted magnetite nanoparticles, coated with citric acid and pluronic F127 for hyperthermia application. Phys. B Condens. Matter 2022, 625, 413468. [CrossRef]

160. Alotaibi, I.; Alshammari, M.S.; Algessair, S.; Madkhali, N.; All, N.A.; Hjiri, M.; Alrub, S.A.; El Mir, L.; Lemine, O.M. Synthesis, characterization and heating efficiency of $\mathrm{Gd}$-doped maghemite $\left(\gamma-\mathrm{Fe}_{2} \mathrm{O}_{3}\right)$ nanoparticles for hyperthermia application. Phys. $B$ Condens. Matter 2022, 625, 413510. [CrossRef]

161. Hajalilou, A.; Ferreira, L.P.; Melo Jorge, M.E.; Reis, C.P.; Cruz, M.M. Superparamagnetic Ag-Fe ${ }_{3} \mathrm{O}_{4}$ composites nanoparticles for magnetic fluid hyperthermia. J. Magn. Magn. Mater. 2021, 537, 168242. [CrossRef]

162. Rajan, A.; Kaczmarek-Szczepańskac, B.; Sahu, N.K. Magneto-thermal response of $\mathrm{Fe}_{3} \mathrm{O}_{4} @ \mathrm{CTAB}$ nanoparticles for cancer hyperthermia applications. Mater. Today Commun. 2021, 28, 102583. [CrossRef]

163. Nam, P.H.; Phuc, N.X.; Manh, D.H.; Tung, D.K.; Nguyen, V.Q.; Nam, N.H.; Son, P.K.; Bach, T.N.; Phong, P.T. Physical characterization and heating efficacy of chitosan-coated cobalt ferrite nanoparticles for hyperthermia application. Phys. E Low-Dimens. Syst. Nanostructures 2021, 134, 114862. [CrossRef]

164. Kurian, J.; Lahiri, B.B.; Mathew, M.J.; Philip, J. High magnetic fluid hyperthermia efficiency in copper ferrite nanoparticles prepared by solvothermal and hydrothermal methods. J. Magn. Magn. Mater. 2021, 538, 168233. [CrossRef]

165. Patade, S.R.; Andhare, D.D.; Somvanshi, S.B.; Jadhav, S.A.; Khedkar, M.V.; Jadhav, K.M. Self-heating evaluation of superparamagnetic $\mathrm{MnFe}_{2} \mathrm{O}_{4}$ nanoparticles for magnetic fluid hyperthermia application towards cancer treatment. Ceram. Int. 2020, 46, 25576-25583. [CrossRef]

166. Schuemann, J.; Bagley, A.F.; Berbeco, R.; Bromma, K.; Butterworth, K.T.; Byrne, H.L.; Chithrani, B.D.; Cho, S.H.; Cook, J.R.; Favaudon, V. Roadmap for metal nanoparticles in radiation therapy: Current status, translational challenges, and future directions. Phys. Med. Biol. 2020, 65, 21RM02. [CrossRef] [PubMed]

167. Liu, W.; Chen, B.; Zheng, H.; Xing, Y.; Chen, G.; Zhou, P.; Qian, L.; Min, Y. Advances of Nanomedicine in Radiotherapy. Pharmaceutics 2021, 13, 1757. [CrossRef] [PubMed]

168. Turnbull, T.; Douglass, M.; Williamson, N.H.; Howard, D.; Bhardwaj, R.; Lawrence, M.; Paterson, D.J.; Bezak, E.; Thierry, B.; Kempson, I.M. Cross-Correlative Single-Cell Analysis Reveals Biological Mechanisms of Nanoparticle Radiosensitization. ACS Nano 2019, 13, 5077-5090. [CrossRef]

169. Penninckx, S.; Heuskin, A.-C.; Michiels, C.; Lucas, S. Thioredoxin Reductase Activity Predicts Gold Nanoparticle Radiosensitization Effect. Nanomaterials 2019, 9, 295. [CrossRef]

170. Zhang, C.; Yan, L.; Gu, Z.; Zhao, Y. Strategies based on metal-based nanoparticles for hypoxic-tumor radiotherapy. Chem. Sci. 2019, 10, 6932-6943. [CrossRef]

171. Chen, Y.; Zhong, H.; Wang, J.; Wan, X.; Li, Y.; Pan, W.; Li, N.; Tang, B. Catalase-like metal-organic framework nanoparticles to enhance radiotherapy in hypoxic cancer and prevent cancer recurrence. Chem. Sci. 2019, 10, 5773-5778. [CrossRef]

172. Niculescu, A.-G.; Grumezescu, A.M. Photodynamic Therapy-An Up-to-Date Review. Appl. Sci. 2021, 11, 3626. [CrossRef]

173. Sharker, S.M. Nanoparticle for Photoresponsive Minimal-Invasive Cancer Therapy. In Cancer Nanotheranostics. Nanotechnology in the Life Sciences; Springer: Cham, Switzerland; Berlin/Heidelberg, Germany, 2021; pp. 201-216.

174. Rimza, T.; Singh, S.; Kumar, P. Chapter 19-Two-dimensional nanomaterials for cancer application. In Biosensor Based Advanced Cancer Diagnostics; Khan, R., Parihar, A., Sanghi, S.K., Eds.; Academic Press: Cambridge, MA, USA, 2022; pp. 321-331.

175. Sharker, S.M.; Kim, S.M.; Lee, J.E.; Choi, K.H.; Shin, G.; Lee, S.; Lee, K.D.; Jeong, J.H.; Lee, H.; Park, S.Y. Functionalized biocompatible WO3 nanoparticles for triggered and targeted in vitro and in vivo photothermal therapy. J. Control. Release Off. J. Control. Release Soc. 2015, 217, 211-220. [CrossRef]

176. Sun, X.; Sun, M.; Liu, M.; Yuan, B.; Gao, W.; Rao, W.; Liu, J. Shape tunable gallium nanorods mediated tumor enhanced ablation through near-infrared photothermal therapy. Nanoscale 2019, 11, 2655-2667. [CrossRef]

177. Yang, N.; Gong, F.; Zhou, Y.; Hao, Y.; Dong, Z.; Lei, H.; Zhong, L.; Yang, X.; Wang, X.; Zhao, Y.; et al. A general in-situ reduction method to prepare core-shell liquid-metal / metal nanoparticles for photothermally enhanced catalytic cancer therapy. Biomaterials 2021, 277, 121125. [CrossRef] [PubMed]

178. Bhapkar, S.; Kumbhar, N.; Gacche, R.; Jagtap, S.; Jadhav, U. Photodynamic Therapy (PDT): An Alternative Approach for Combating COVID-19. Biointerface Res. Appl. Chem. 2021, 11, 12808-12830. [CrossRef]

179. Wang, Q.; Zhang, X.; Sun, Y.; Wang, L.; Ding, L.; Zhu, W.-H.; Di, W.; Duan, Y.-R. Gold-caged copolymer nanoparticles as multimodal synergistic photodynamic/photothermal/chemotherapy platform against lethality androgen-resistant prostate cancer. Biomaterials 2019, 212, 73-86. [CrossRef] [PubMed]

180. Tabero, A.; Planas, O.; Gallavardin, T.; Nieves, I.; Nonell, S.; Villanueva, A. Smart Dual-Functionalized Gold Nanoclusters for Spatio-Temporally Controlled Delivery of Combined Chemo-and Photodynamic Therapy. Nanomaterials 2020, 10, 2474. [CrossRef] [PubMed]

181. Canaparo, R.; Foglietta, F.; Limongi, T.; Serpe, L. Biomedical Applications of Reactive Oxygen Species Generation by Metal Nanoparticles. Materials 2021, 14, 53. [CrossRef]

182. Vighetto, V.; Ancona, A.; Racca, L.; Limongi, T.; Troia, A.; Canavese, G.; Cauda, V. The synergistic effect of nanocrystals combined with ultrasound in the generation of reactive oxygen species for biomedical applications. Front. Bioeng. Biotechnol. 2019, 7, 374 [CrossRef] 
183. Yang, L.; Gao, M.X.; Zhan, L.; Gong, M.; Zhen, S.J.; Huang, C.Z. An enzyme-induced Au@Ag core-shell nanoStructure used for an ultrasensitive surface-enhanced Raman scattering immunoassay of cancer biomarkers. Nanoscale 2017, 9, 2640-2645. [CrossRef]

184. Pallares, R.M.; Thanh, N.T.K.; Su, X. Sensing of circulating cancer biomarkers with metal nanoparticles. Nanoscale 2019, 11, 22152-22171. [CrossRef]

185. Nikolopoulou, S.G.; Boukos, N.; Sakellis, E.; Efthimiadou, E.K. Synthesis of biocompatible silver nanoparticles by a modified polyol method for theranostic applications: Studies on red blood cells, internalization ability and antibacterial activity. J. Inorg. Biochem. 2020, 211, 111177. [CrossRef]

186. Vo, T.M.T.; Mondal, S.; Nguyen, V.T.; Park, S.; Choi, J.; Bui, N.T.; Oh, J. Rice starch coated iron oxide nanoparticles: A theranostic probe for photoacoustic imaging-guided photothermal cancer therapy. Int. J. Biol. Macromol. 2021, 183, 55-67. [CrossRef]

187. Divband, B.; Gharehaghaji, N.; Atashi, Z. High Transverse Relaxivity and Anticancer Agent Loading/Release Characteristics of Porous Calcium Phosphate Coated Iron Oxide Nanoparticles. Biointerface Res. Appl. Chem. 2021, 11, 10402-10411. [CrossRef]

188. Santos, E.C.S.; Cunha, J.A.; Martins, M.G.; Galeano-Villar, B.M.; Caraballo-Vivas, R.J.; Leite, P.B.; Rossi, A.L.; Garcia, F.; Finotelli, P.V.; Ferraz, H.C. Curcuminoids-conjugated multicore magnetic nanoparticles: Design and characterization of a potential theranostic nanoplatform. J. Alloy. Compd. 2021, 879, 160448. [CrossRef]

189. Shariati, M. The cancer therapy materialization by theranostic nanoparticles based on gold doped iron oxide under electromagnetic field amplification. Nanomed. Nanotechnol. Biol. Med. 2021, 35, 102406. [CrossRef] [PubMed]

190. Zhang, H.; Zhang, L.; Zhong, H.; Niu, S.; Ding, C.; Lv, S. Iridium oxide nanoparticles-based theranostic probe for in vivo tumor imaging and synergistic chem/photothermal treatments of cancer cells. Chem. Eng. J. 2022, 430, 132675. [CrossRef]

191. Shi, H.; Suo, Y.; Zhang, Z.; Liu, R.; Liu, H.; Cheng, Z. Copper(II)-disulfiram loaded melanin-dots for cancer theranostics. Nanomed. Nanotechnol. Biol. Med. 2021, 32, 102340. [CrossRef]

192. Cheng, L.; Sang, D.; Zhao, F.; Yang, L.; Guo, Z.; Zhang, X.; Yang, Q.; Qiao, W.; Sun, X.; Guan, X.; et al. Magnetic Resonance/Infrared Dual-Modal Imaging-Guided Synergistic Photothermal/Photodynamic Therapy Nanoplatform Based on Cu1.96S-Gd@FA for Precision Cancer Theranostics. J. Colloid Interface Sci. 2022, 615, 95-109. [CrossRef]

193. Nosrati, H.; Attari, E.; Abhari, F.; Barsbay, M.; Ghaffarlou, M.; Mousazadeh, N.; Vaezi, R.; Kavetskyy, T.; Rezaeejam, H.; Webster, T.J.; et al. Complete ablation of tumors using synchronous chemoradiation with bimetallic theranostic nanoparticles. Bioact. Mater. 2022, 7, 74-84. [CrossRef] 